\title{
THE ANTITRUST LAWS AND PROFESSIONAL DISCIPLINE IN MEDICINE
}

\author{
Frank P. GRAD*
}

\section{INTRODUCTION}

The decision in Goldfarb v. Virginia State Bar ${ }^{1}$ in 1975 began a new chapter in the application of the antitrust laws to the professions and their professional organizations. The prosecution of professional organizations, and particularly of organized medicine, under the antitrust laws is not an entirely new development, however, because professional organizations had been involved in antitrust litigation long before Goldfarb. ${ }^{2}$ The peculiarities of medical discipline make organized medicine a good object for Federal Trade Commission inquiry and for antitrust enforcement.

The regulation of medical practice-or the discipline of physicians- has long been a state police power concern as well as a matter for professional self-regulation. One of the difficulties of medical discipline is the lack of a single consistent structure. Instead, a number of levels of state and private regulatory efforts exist, to which another level of federally stimulated peer and utilization review has been added in the years since the advent of Medicare and Medicaid which further requires both state and private organizational involvement. These separate layers of professional discipline overlap at many points and provide opportunities not only for ethical self-regulation but also for selfprotective economic restraint and abuse.

An inherent and recurrent problem in the regulation of any profession is professionalism itself. Only physicians know enough to judge

* Professor of Law, Columbia Law School; Director, Legislative Drafting Research Fund, Columbia University; B.A. 1947, Brooklyn College; LL.B. 1949, Columbia Law School. The author gratefully acknowledges the research assistance of Kenneth Gibson and Barry Mills (Columbia Law Students, Class of 1979) in the preparation of this Article.

THE FOLLOWING CITATIONS WILL BE USED IN THIS ARTICLE:

R. Derbyshire, Medical Licensure and Discipline in the United States (1969) [hereinafter cited as $R$. DERBYSHIRE];

F. Grad \& N. Marti, Legislative Drafting Research Fund of Columbia UniverSITY, Study of Medical Disciplinary Procedures (Final Report Under Contract No. PHS 282-76-0452-65, submitted Feb. 16, 1978) [hereinafter cited as GRAD].

1. 421 U.S. 773 (1975).

2. See, eg., United States v. Oregon Medical Soc'y, 343 U.S. 326 (1952); American Medical Ass'n v. United States, 317 U.S. 519 (1943). 
whether a physician's professional performance meets minimum professional standards, just as only lawyers are capable of judging another lawyer's professional performance. In any profession, codes of ethics are needed to provide a measure of professional competence. By the same token, limiting professional practice to the professionally competent involves the exclusion of some from practice. Invariably a question arises whether standards-either those contained in codes of professional ethics or in medical practice acts-are designed to protect the public against unscrupulous or incompetent practitioners, or whether they merely protect insiders against competition in violation of the antitrust laws. It is not always easy to tell which of these purposes is being advanced, and it is precisely in this area of doubt that abuses are found and antitrust claims are raised.

Following a brief discussion of antitrust doctrines with special relevance to professional regulation, this Article will focus on the methods of medical regulation. The discussion will commence with an account of the official state regulatory scheme of physician licensure and official discipline. It will continue with an examination of the private disciplinary controls exercised by state and county medical societies, by hospitals through the grant and denial of privileges, and by private national boards through specialty certification. Finally, the federally required schemes of utilization review and peer review by professional standard review organizations (PSROs) will be considered. The analysis will identify the points of contact between the various levels of control and will examine the potential for antitrust violations in the context of each separate layer.

\section{ANtitrust Doctrines With Special ReleVANCE to Medical Practice}

Medical practice is regulated by the state and by non-governmental professional societies, sometimes by special delegation from the state. A number of doctrines or exemptions with special and recurring relevance in the application of the antitrust laws to the practice of professions have been discussed in several recent trend-setting decisions ${ }^{3}$ and these doctrines will be analyzed briefly below.

3. National Soc'y of Professional Eng'rs v. United States, 98 S.Ct. 2923 (1978); Bates v. State Bar of Ariz., 433 U.S. 350 (1977); Cantor v. Detroit Edison Co., 428 U.S. 579 (1976); Virginia State Bd. of Pharmacy v. Virginia Citizens Consumer Council, 425 U.S. 748 (1976); Goldfarb v. Virginia State Bar, 421 U.S. 773 (1975). 


\section{A. Some Comments on Parker v. Brown-The State Action Exemption.}

State regulation of a profession or occupation invariably creates access barriers and some limitations on the conduct of economic activities, or, in a general sense, restraints of trade. The recurring issue is whether the Sherman Act allows state regulatory activity that has anticompetitive effects, or whether it brings state agencies under its scope, raising the possibility of the prosecution of state agencies for Sherman Act violations. ${ }^{4}$ The so-called state action doctrine, exempting certain state activities from the application of the Sherman Act, had its beginning in Parker v. Brown. ${ }^{5}$ The answer here suggested is that regulatory actions within the traditional scope of the police power to protect health, safety and welfare are not subject to antitrust enforcement, even though such exercises of the police power may have incidental anticompetitive or restraint of trade effects. It is likely, therefore, that state regulation of medical practice will continue free from Sherman Act intervention, unless such regulation exceeds its traditional scope or merely uses the form of state law to advance private economic interests.

The broad sweep of the doctrine as originally pronounced ${ }^{6}$ would have barred all efforts to bring professions regulated under state law within the ambit of the antitrust laws. However, in 1975 the Supreme Court reexamined this exemption policy in Goldfarb, where the minimum fee schedule of a county bar association was challenged under the Sherman Act. A state statute had assigned the task of regulating the legal profession to the state supreme court, which had delegated its administrative duties to the state bar. The county bar claimed that its fee schedule was "prompted" by the state bar and was exempt from the

4. See generally Bauer, Professional Activities and the Antitrust Laws, 50 Notre Dame LAw. 570 (1975); Blackstone, The A.M.A. and the Osteopaths: A Study of the Power of Organized Medicine, 22 ANTITRUST BuLl. 405 (1977); Craver, The Application of Labor and Antitrust Laws to Physician Unions: The Need for a Re-Evaluation of Traditional Concepts in a Radically Changing Field, 27 Hastings L.J. 55 (1975); Handler, The Current Attack on the Parker v. Brown State Action Doctrine, 76 Colum. L. Rev. 1 (1976); Handler, Twenty-fourth Annual Antitrust Review, 72 Colum. L. Rev. 1, 4-18 (1972); Kaplin, Professional Power and Judicial Review: The Health Professions, 44 Geo. WaSH. L. Rev. 710 (1976); Verkuil, State Action, Due Process and Antitrust: Reflections on Parker v. Brown, 75 Colum. L. Rev. 328 (1975); Wallace, Occupational Licensing and Certification: Remedies for Denial, 14 WM. \& MARY L. REv. 46, 89-127 (1972); Note, Parker v. Brown Revisited: The State Action Doctrine After Goldfarb, Cantor and Bates, 77 Colum. L. Rev. 898 (1977).

5. 317 U.S. 341 (1943).

6. Id. at 350-51. The Parker Court held that the Sherman Act was designed "to suppress combinations to restrain competition and attempts to monopolize by individuals and corporations." Id. at 351. The Court found "nothing in the language of the Sherman Act or in its history which suggests that its purpose was to restrain a state or its officers or agents from activities directed by its legislature." Id. at $350-51$. 
Sherman Act under Parker. ${ }^{7}$ Finding no statutory mandate to create price floors, the Supreme Court held that these anticompetitive minimum fee schedules were not directed by the state acting as a sovereign, and that consequently they were not exempt from antitrust enforcement. The Court's analysis indicates that a state agency acting pursuant to an explicit legislative mandate will be covered by the Parker exemption. However, if the state agency is acting ultra vires, the regulatory agency will not be exempt from antitrust action. ${ }^{8}$

After Goldfarb, for the state action exemption to apply, state regulatory agencies have the burden of showing, at the very least, that any anticompetitive restrictions which their regulations have imposed are "compelled by" state law. There has been much discussion of the question whether the agency must satisfy this burden by pointing to an explicit legislative mandate or may imply its authority from a general legislative intent. ${ }^{9}$ Though much of the discussion of the Parker exemption focuses on the explicitness of the legislative direction, most of this discussion is superficial and probably beside the point. ${ }^{10}$ The real issue-which is increasingly being addressed in the cases after Goldfarb-is the extent to which the Sherman Act may interfere with the regular exercise of the states' police power. ${ }^{11}$ As Milton Handler has warned, the Sherman Act should not be permitted to serve as a basis for the broad invalidation of state law, serving the same questionable purpose as the earlier doctrine of substantive due process. ${ }^{12}$

The state action defense was successfully asserted after Goldfarb in Bates v. State Bar of Arizona ${ }^{13}$ where the Supreme Court, though invalidating on first amendment grounds the ban on legal advertising, rejected the claim under the federal antitrust law because restrictions on advertising were explicitly required by the Supreme Court of Ari-

7. 421 U.S. at 790 .

8. Here, the state bar joined what was essentially a private anticompetitive effort. "The fact that the State Bar is a state agency for some limited purposes does not create an antitrust shield that allows it to foster anticompetitive practices for the benefit of its members." Id. at 791.

9. See generally Branca \& Steinberg, Attorney Fee Schedules and Legal Advertising: The Implications of Goldfarb, 24 U.C.L.A. L. REv. 475 (1977); Tyler, Goldfarb v. Virginia State Bar: The Professions are Subject to the Sherman Act, 41 Mo. L. REv. 1 (1976); Comment, Antitrust-Goldfarb v. Virginia State Bar-Professional Legal Services are Held to be Within the Ambit of Federal Antitrust Laws, 7 LoY. CHI. L.J. 254 (1976).

10. The issue of an "explicit" as against a "general" legislative mandate-with the explicit mandate surviving and the general mandate yielding to the Sherman Act-loses much of its force in the light of the fact that an agency's primary regulatory purpose is most likely to be expressed in explicit, rather than general terms.

11. See, e.g., Bates v. State Bar of Ariz., 433 U.S. 350 (1977).

12. Handler, The Current Attack on the Parker v. Brown State Action Doctrine, supra note 4, at 6-7, 16-17.

13. 433 U.S. 350 (1977). 
zona, the "ultimate body wielding the State's power over practice of law" pursuant to the state constitution. ${ }^{14}$ Because the state had adopted a rule which restricted advertising, a rule which was part of its regulation of the practice of law, the Supreme Court held that the Arizona Bar was carrying out state law and was, therefore, entitled to state action immunity. In analyzing Parker v. Brown, the Bates Court followed the method of analysis employed by the Court in Goldfarb, namely that the "threshold inquiry" was "whether the activity is required by the State acting as sovereign." 15

Nonetheless, the state action immunity may not be available even where a governmental entity is directly involved. In City of Lafayette $v$. Louisiana Power \& Light Co., ${ }^{16}$ the Supreme Court faced a counterclaim by a utility company that a city utility regulatory agency and two Louisiana cities had violated the antitrust laws. The charges included assertions of conspiracies in restraint of trade, including sham litigation to delay the power company's construction of a nuclear power plant; the inclusion of covenants in the cities' debentures that prevented competition in the provision of power; conspiracies relating to the designation of service areas; and tie-in requirements with respect to the purchase of electricity from the city to obtain gas and water services. In a five to four decision, with the majority split three and the dissent two ways, the Court affirmed the decision of the court of appeals that a valid cause of action had been stated. The only issue on which a majority of the Court could agree was that municipalities do not necessarily share in the Parker state action exception. The decision is not inconsistent, however, with an analysis which stresses antitrust immunity for traditional exercises of the police power; both the majority and the dissenters would have applied the Parker exception to "an act of government by the State as sovereign." 17 The facts alleged, however, clearly raised a question whether the two cities had gone beyond the exercise of normal regulatory powers encompassed in the police power. ${ }^{18}$ Applications of the Sherman Act to state and local governmental activities have also been upheld in other instances where these governments

14. Id. at 360 .

15. 421 U.S. at 790.

16. 98 S. Ct. 1123 (1978).

17. Id. at 1137,1145 .

18. The Court remanded the case for a determination of whether the challenged activity was authorized by the state. In interpreting Goldfarb, the plurality held that a specific statutory command by the state legislature was not required. Sufficient state authority exists, it found, if the court is able to ascertain, " from the authority given a governmental entity to operate in a particular area, that the legislature contemplated the kind of action complained of.' "Id. at 1138 (quoting City of Lafayette v. Louisiana Power \& Light Co., 532 F.2d 431, 434 (1977)). 


\section{acted in a non-regulatory manner. ${ }^{19}$}

It seems that the formulation of Goldfarb accords with this analysis. Under Goldfarb, a public official who carries out a requirement of state law is protected by the Parker doctrine if the activity is an exercise of the power of the state acting as a sovereign. The state clearly acts as a sovereign when it acts within the scope of its traditional powers to protect health, safety and welfare-i.e., within the traditional scope of the police power. This analysis is further supported by cases that involve the state action exemption dealing with anticompetitive activity of private individuals allegedly under the direction of the state.

In Cantor v. Detroit Edison Co. ${ }^{20}$ an important analytical sequel to Goldfarb, a private utility company was charged with restraining competition in the sale of light bulbs, which the company provided free to its customers, though the cost of the program was included in the rate scale approved by the state regulatory agency. Justice Stevens, in rejecting the application of the Parker defense, ${ }^{21}$ developed a test for state action immunity for private individuals acting under state law. In his view, to be exempt the private action must be compelled by a state law or regulation, and the state must take an extensive role-and not merely acquiesce-in the formulation of the allegedly anticompetitive

19. In Duke \& Co. v. Foerster, 521 F.2d 1277 (3d Cir. 1975), county officials and concessionaires were found subject to the Sherman Act for an alleged conspiracy to bar the sale of plaintiff's malt beverages at municipal facilities. In Allegheny Uniforms v. Howard Uniform Co., 384 F. Supp. 460 (W.D. Pa. 1974), the State Port Authority was sued for restricting a manufacturer's opportunity to sell his uniforms to Authority employees by requiring employees to purchase uniforms manufactured by a specified manufacturer. In both of these cases Parker did not protect the public agencies. Neither the power to regulate municipal facilities nor the power to regulate the affairs of the port required interference with competition in the sale of malt beverages or in the sale of uniforms-the ordinary scope of the respective agencies' regulatory powers did not include, even incidentally, such restriction of competition as part of the regulatory scheme. See also Brenner v. State Bd. of Motor Vehicle Mfgs., Dealers and Salesmen, 413 F. Supp. 639 (E.D. $\mathrm{Pa}$. 1976) (state administrative agency has burden of showing that its regulations are compelled by the state).

20. 428 U.S. 579 (1976).

21. Mr. Justice Stevens, writing for a divided Court, noted that the carefully drafted language in Parker unequivocally differentiates between official action and individual action even when commanded by the state and added: "Since the case now before us does not call into question the legality of any act of the State of Michigan or any of its officials or agents, it is not controlled by the Parker decision." Yd. at $591-92$ \& n.24.

Mr. Justice Blackmun, concurring with Mr. Justice Stevens, suggested a balancing test to determine the legality of state-sanctioned anticompetitive activity. The potential harms of the regulations should be weighed against the benefits to be gained by restrictions on competition. State action designed to protect health and safety would be presumed immune from antitrust action. "I would assess the justifications of such enactments in the same way as is done in equal protection review, and where such justifications are at all substantial (as one would expect them to be in the case of most professional licensing or fee-setting schemes . . .), I would be reluctant to find the restraint unreasonable." $I d$. at 611 (emphasis added). 
policy. The activities of the private individual must be required by, or directly carry out, the state regulation. If the state regulatory policy is in conflict with the policy of the federal antitrust laws, an exemption, to the minimum extent necessary, will be implied to make the state act work. Finally, the state's regulatory interest which results in limiting competition must outweigh the federal antitrust policy. ${ }^{22}$ The Cantor case, on its facts, failed to meet any of these standards, for state utility regulations neither required nor regarded as essential the anticompetitive restriction on the sale of light bulbs.

An examination of recent decisions interpreting the Parker state action doctrine leads to the conclusion that the doctrine is alive and well as applied to traditional and accepted exercises of the police power to protect health, safety and welfare. Exercises of proprietary powers are suspect, as are economic regulations not incident to, or within the scope of, the delegated regulatory powers within the agency's jurisdiction. If the state agency is held to be acting beyond its mandate, the Court is likely to apply the standard developed in Cantor to determine the scope of antitrust immunity for private individuals acting under a state regulation. ${ }^{23}$

It is likely that state regulations of medical practice which reflect the application of the police power for the protection of the public will be upheld as exempt from antitrust laws even if they incidentally operate to limit competition. On the other hand, regulations issued by medical societies under color of state law will have to meet a more stringent test. $^{24}$

B. The Noerr-Pennington Doctrine-Antitrust Law, State Action, and the Right to Petition and Complain.

The Noerr-Pennington ${ }^{25}$ doctrine, rooted in first amendment policy, basically states that the Sherman Act should not interfere with the right to communicate with public officials. ${ }^{26}$ This right to petition pub-

22. Id. at 596 .

23. For lower courts that have followed Cantor, see City of Mishawaka v. Indiana \& Michigan Elec. Co., 560 F.2d 1314 (7th Cir. 1977); Whitworth v. Perkins, 559 F.2d 378 (5th Cir. 1977); Kurek v. Pleasure Driveway and Park Dist., 557 F.2d 580 (7th Cir. 1977); Surety Title Ins. Agency, Inc. v. Virginia State Bar, 431 F. Supp. 298 (E.D. Va. 1977). For a somewhat similar, though more detailed, independent analysis, see Note, supra note 4.

24. See Handler, Twenty-fourth Annual Antitrust Review, supra note 4, at 11. See also Hennessey v. NCAA, 564 F.2d 1136 (5th Cir. 1977); City of Fairfax v. Fairfax Hosp. Ass'n, 562 F.2d 280 (4th Cir. 1977).

25. UMW v. Pennington, 381 U.S. 657 (1965); Eastern R.R. Presidents Conference v. Noerr Motor Freight, Inc., 365 U.S. 127 (1961).

26. For a discussion of the Noerr-Pennington doctrine, see Note, Physician Influence: Applying Noerr-Pennington to the Medical Profession, 1978 Duke L.J. 701. See also Costilo, Anti- 
lic officials is limited neither by the anticompetitive purposes of the petitioner nor by the fact that it forms part of an otherwise illegal scheme. ${ }^{27}$ The doctrine finds ready opportunities for application in fields of professional regulation where the members of the regulated group may find occasion to appeal or complain to government agencies for regulation and enforcement that will raise professional standards by keeping out allegedly less well-trained, less ethical or less highly professional competitors who happen to charge less for their services. ${ }^{28}$

With functions of professional discipline and the regulation of medical practice divided up among layers of government agencies and private organizations, the application of the Noerr-Pennington doctrine often runs into the question of whether the complaint was indeed addressed to a legislative or executive organ of government or whether it was addressed to a person or body not a government, but an instrumentality of professional governance-i.e., whether the petitioner or complainant spoke to the government, or merely to himself. So, for instance, in Feminist Women's Health Center, Inc. v. Mohammad, the Noerr-Pennington doctrine was held inapplicable to certain allegedly official conversations with members of a hospital staff and leading members of a local medical society, though it was held applicable to conversations with the executive director of the state board of medical examiners. $^{29}$

\section{The Learned Profession Exemption.}

If learned professions such as medicine were entirely exempt from antitrust regulation, private medical societies would be free to engage

trust's Newest Quagmire: The Noerr-Pennington Defense, $66 \mathrm{MicH}$. L. Rev. 333 (1967); Handler, Twenty-fourth Annual Antitrust Review, supra note 4, at 11-12; Comment, Governmental Action and Antitrust Immunity, 119 U. PA. L. Rev. 521, 523-25 (1971); Note, Application of the Sherman Act to Attempts to Infiuence Government Action, 81 HARv. L. REv. 847, 848-54 (1968). For the so-called "sham exception" to Noerr-Pennington, see California Motor Transport Co. v. Trucking Unlimited, 404 U.S. 508 (1972).

27. "Joint efforts to influence public officials do not violate the antitrust laws even though intended to eliminate competition. Such conduct is not illegal, either standing alone or as part of a broader scheme itself violative of the Sherman Act." UMW v. Pennington, 381 U.S. 657, 670 (1965).

28. See, e.g., United States Dental Inst. v. American Ass'n of Orthodontists, 396 F. Supp. 565 (N.D. Ill. 1975).

29. 415 F. Supp. 1258 (N.D. Fla. 1976). The case involved an alleged conspiracy of economic boycott of the Feminist Women's Health Center, which provided first trimester elective abortions for a fee of $\$ 150$. During the alleged boycott no local physician would work at the Center. The physicians charged in the conspiracy, all of whom performed their services at the Tallahassee Memorial Hospital (TMH), charged $\$ 400$. Evidence submitted on a motion for a preliminary injunction indicated that the TMH obstetric/gynecological staff, which passes on physicians who practice at that hospital, had decided by resolution that it would not approve the Feminist Center unless a TMH staff member was a member of the clinic. Following advertising and favorable 
in anticompetitive self-regulation without any accountability. It had been assumed for some time that the learned professions were exempt from antitrust prosecution because professional activity was not considered "trade or commerce" within the meaning of the Sherman Act. ${ }^{30}$ Although there had never been a clear holding that such an exemption was to be applied to the medical profession, dicta in several cases supported the idea that professions were to be treated differently from ordinary businesses. ${ }^{31}$

The claim that the learned professions are exempt from the Sherman Act because they do not engage in "trade or commerce" was clearly rejected in Goldfarb. The Supreme Court noted that there is neither a specific exemption for professions on the face of the Sherman Act, nor any legislative history to indicate that the professions were not intended to be covered by the terms "trade or commerce."32

While the Goldfarb Court held that professions are not exempt from Sherman Act jurisdiction, it did suggest, in what has become one of its notable footnotes, that restraints on competition in professionals' activity would not be analyzed according to the same standards as restraints on purely commercial activity.

The fact that a restraint operates upon a profession as distinguished from a business is, of course, relevant in determining whether that particular restraint violates the Sherman Act. It would be unrealistic to view the practice of professions as interchangeable with other business activities, and automatically to apply to the professions antitrust concepts which originated in other areas. The public service aspect, and other features of the professions, may require that a particular practice, which could properly be viewed as a violation of

publicity for the Center, an opinion on the ethical propriety of the Center was sought from the local Capitol Medical Society. Other communication asserting inadequate physician backup service for the Center included a letter to one of the defendants, Dr. Palmer, the Director of the Florida Board of Medical Examiners. The district court upheld the Noerr-Pennington defense with respect to communications with Dr. Palmer (though there was only questionable evidence that the communication was in his official capacity), but held the defense inapplicable to other conversations, because the TMH ob/gyn staff was not a regulatory body, and neither was the Capitol Medical Society.

The court subsequently reversed itself and granted summary judgment for the defendants after finding that the hospital staff and the Capital Medical Society were addressed and petitioned in their "quasi-governmental" capacity and that consequently Noerr-Pennington applied. Memorandum of Decision, No. TCA 75-186 (N.D. Fla. Dec. 3, 1976).

30. For a pre-Goldfarb discussion of the learned professions exemption, see Bauer, supra note 4 , at $571-92$.

31. See United States v. Oregon Medical Soc'y, 343 U.S. 326, 336 (1952); FTC v. Raladam Co., 283 U.S. 643, 653 (1931).

32. 421 U.S. at 786-88. The Court also cited Associated Press v. United States, 326 U.S. 1, 7 (1945), and United States v. National Ass'n of Real Estate Bds., 339 U.S. 485, 489 (1950), to support the proposition that the nature of an occupation, including its public service aspect, by itself does not determine its exemption vel non from the Sherman Act. 421 U.S. at 787. 
the Sherman Act in another context, be treated differently. We intimate no view on any other situation than the one with which we are confronted today. ${ }^{33}$

Despite this qualifying footnote, which implies a "rule of reason" approach, the Court proceeded to treat the minimum fee schedule as a per se violation of the Sherman Act. ${ }^{34}$ The full significance of this footnote has yet to be explained by the Supreme Court. Presumably there are restraints which are illegal per se in the commercial sphere which are valid restraints when applied in the professional sphere.

Some insight into the analysis the Court may use in differentiating professional regulation and activity from purely commercial activity may be gleaned from recent cases challenging advertising restraints. Though the issues concerning the right to prohibit advertising in Virginia State Board of Pharmacy v. Virginia Citizens Consumer Council ${ }^{35}$ and in Bates were decided on first amendment grounds, these opinions closely parallel the "rule of reason" analysis of antitrust cases. ${ }^{36}$

In Virginia State Board of Pharmacy, the pharmacists argued that price competition resulting from advertising would lower the professional caliber of pharmacists and jeopardize the health and safety of the public. The Supreme Court rejected the latter argument, emphasizing that drugs are standardized products which may be effectively regulated by state agencies that license and regulate their advertisement and sale. ${ }^{37}$ Price advertising could not significantly lower the level of pharmacists' competence because if the products of a certain pharmacist were to fall below the professionally accepted standard because of price cutting, the state pharmacy board had the power to revoke the pharmacist's license. The Court specifically rejected a paternalistic approach toward consumers, expressing its confidence that consumers are fully competent to make an informed choice with respect to both price and

33. 421 U.S. at $788-89$ n.17.

34. Id. at 780-86. See United States v. Socony-Vacuum Oil Co., 310 U.S. 150, 212-18 (1940) (reasonableness of restraints on trade is irrelevant on the question of guilt). On the other hand, note this recent statement in Surety Title Ins. Agency, Inc. v. Virginia State Bar, 431 F. Supp. 298 (E.D. Va. 1977): "There is a split of authority as to whether the per se or rule of reason test should be applied to substantive antitrust claims involving the practices of professions [comparing United States v. National Soc'y of Professional Eng'rs, 555 F.2d 978 (D.C. Cir. 1977), with Feminist Women's Health Center, Inc. v. Mohammad, 415 F. Supp. 1258, 1263 (N.D. Fla. 1976)]." 431 F. Supp. at 304 n.8.

35. 425 U.S. 748 (1976).

36. For an articulation of the "rule of reason," see Standard Oil Co. v. United States, 221 U.S. 1 (1911); United States v. American Tobacco Co., 221 U.S. 106 (1911). For an application of the "rule of reason" in a professional context, see United States v. Oregon State Bar, 385 F. Supp. 507 (D. Or. 1974), requiring a balancing of "the various harms and benefits occasioned to the public by the conduct in question." Id. at 516 .

37. 425 U.S. at 767-69. 
service if they have the facts. ${ }^{38}$

In a footnote to its opinion the Court noted that its decision had no bearing on advertising restrictions on members of other professions, such as lawyers or physicians. The Court re-emphasized the distinction noted in Goldfarb between professionals who deal in services and businessmen who deal in products. ${ }^{39}$ Chief Justice Burger also emphasized this distinction in his concurring opinion. ${ }^{40}$

In Bates, the Court similarly struck down anticompetitive restrictions on price advertising of certain standard legal services. The arguments made in support of an advertising ban for the services of professionals are generally similar to arguments of professionals in support of anticompetitive restraints alleged to protect professionalism: namely, that advertising demeans the profession and undermines respect for it; that it destroys the maintenance of professionalism, as distinguished from the mere conduct of a trade; that it would be inherently misleading to the public in that it would not provide adequate information relating to the nature of the services advertised; that it would have undesirable economic effects by increasing prices but lowering the quality of professional service; and that it would be very difficult to enforce regulations to protect against misleading advertising. The Court rejected these arguments, finding that the potential benefits of advertising standard legal services outweighed the predicted dangers, many of which the Court believed did not exist. ${ }^{41}$

It is also important to note that the Court rejected the assertion that ethical self-discipline of the legal profession would not control advertising abuse. The Court thought that the profession would best be served if the professional self-regulation mechanisms actively maintain and enforce its standards. ${ }^{42}$

The lower federal courts faced with the task of interpreting Goldfarb have enunciated a number of different tests for determining

38. Id. at 769-70.

39. Id. at 773 n.25.

40. Id. at 774-75.

41. 433 U.S. at $366-79$.

42. Id. at 379,384 .

In both Bates and Virginia Board of Pharmacy, the Court placed heavy emphasis on capabilities of regulatory agencies and professional self-discipline to prevent abuses that might otherwise result from greater competition. Apparently, the Court assumes that the benefits to be gained by removing anticompetitive restraints will not adversely affect the quality of professional services because state agencies and professional societies will enforce proper professional standards. Thus, the decisions that purport to create a freer market implicitly support more regulation, since a likely result of increased antitrust enforcement will be a concomitant increase in the level of state regulation to ensure that the caliber of professional service remains high. See id.; 425 U.S. at 768$69,771-72$. 
the validity of anticompetitive restrictions on professional activity. Most of the lower courts have followed the test suggested in the language in footnote 17 of Goldfarb, namely, a rule of reason analysis. The cases approach the issue with the presumption that any anticompetitive activity which would be illegal in a commercial case is illegal in the professional case, unless the presumption is overcome by a showing that the particular restraint should be permitted because of the benefits gained by the public. ${ }^{43}$ If the restraint is perceived by the court as nothing more than a commercial restraint, as in Goldfarb, the presumption is very close to irrebuttable. ${ }^{44}$ The analysis of the first amendment cases suggests that the Supreme Court is not receptive to claims to the validity of anticompetitive regulations based primarily on the protection of professional integrity, professional standing and other status considerations. Applying the rule of reason approach, the lower courts have allowed the professions to justify, on the other grounds, restraints which would be per se illegal if utilized by nonprofessionals. ${ }^{45}$

\section{ANTITRUST Implications OF STATE LiCENSURe AND Professional Control Through Medical Practice ACts AND PeER Review Mechanisms}

Medicine is a thoroughly controlled profession. No person may practice medicine in any part of the United States without a license. ${ }^{46}$ Medical licensure began in the early years of the country, and has

43. See, e.g., Boddicker v. Arizona State Dental Ass'n, 549 F.2d 626 (9th Cir.), cert. denied, 434 U.S. 825 (1977), where the court held that unless the Dental Association could show benefit to the public, in the form of improved service, which resulted from its use of monopoly power to require dentists to be members of the American Dental Association as a condition of membership in the Arizona Dental Association, the professional group would be in violation of the Sherman Act.

44. See, e.g., Ballard v. Blue Shield, 543 F.2d 1075 (4th Cir. 1976), cert. denied, 430 U.S. 922 (1977). In Ballard, a group of chiropractors alleged that physicians, medical associations and private corporations conspired to bar health insurance coverage for chiropractic services. The court stated that this restriction was an "alleged restraint and monopolization of a commercial aspect of the practice of a profession, as distinguished from such other aspects of the professional qualifications of the practitioner," and held that, "the professional status of the physicians affords them no defense." 543 F.2d at 1079. Note that despite the irrebuttable presumption of antitrust violation resulting from the finding that the restraint was purely commercial in character, other anticompetitive activity by professionals will be justifiable under the proper circumstances.

45. See, e.g., Veizaga v. National Bd. of Respiratory Therapy, 1977-1 Trade Cases \ 61,274 (N.D. Ill. 1977), where the court found that the challenged certification procedures would be per se violations in the commercial sense, but instructed the lower court to apply a rule of reason analysis if the restrictions were held to be noncommercial. See notes 43 \& 44 supra and text accompanying notes 142-144 infra.

46. R. DERBYSHIRE 8. The only general exception to state licensure requirements is for physicians employed by the United States, notably physicians in the armed services and the U.S. Public Health Service. See, e.g., N.C. GEN. STAT. \& 90-18(4) (1975). 
spread until it has become a uniform requirement. ${ }^{47} \mathrm{It}$ is clearly a valid exercise of the state's police power. ${ }^{48}$ To become licensed in any state, a physician must be a graduate of an approved school of medicine or osteopathic medicine, must be a person of good moral character, and must pass a state-administered qualifying examination, which is usually a national examination adopted by the state medical board. ${ }^{49}$ In most states, the applicant must also have had clinical training as a resident for one or two years and must pay a license fee. In many states, the applicant must be a citizen of the United States, or must have declared his intention to become a citizen. ${ }^{50}$

The entire licensing process is administered by a state medical board, generally appointed by the governor from lists of nominees submitted by the state or county medical societies. ${ }^{51}$ Until very recently, the state medical boards consisted entirely of physicians, but in recent years the laws have changed, and many state boards now have one or more lay members. ${ }^{52}$ In every state, however, the majority of members are physicians. ${ }^{53}$ In general, the licensing process has been routinized, and there appear to be no recent complaints that the process itself has been abused to limit the number of physicians admitted to practice, even though certain aspects of it operate to limit admission to the field.

The members of the state medical boards are likely to be older, more conservative representatives of the medical establishment who are associated with state and local medical societies. ${ }^{54}$ Absent demonstrated abuses of authority, their licensing activities-even if effective in restricting access to medical practice-presumably come within the state action exemption from the Sherman Act, because in their licens-

47. For a history of medical licensure in America, see R. DERBYSHIRE; R. SHRYOCH, MEDICAL LiCENSING IN AMERICA, 1650-1965 (1967).

48. Dent v. West Virginia, 129 U.S. 114, 122 (1889).

49. For a summary of state licensure requirements in tabular form, see LIAISON COMM. ON Graduate Medical Educ., Directory of Accredited Residencies 1975-1976, 435-37 (1976). See also R. Derbyshire 18-30. For a detailed study of medical licensure laws and medical discipline, see GRAD 54-112.

50. The citizenship requirement, though still found in many state laws, is most certainly of no effect because it is unconstitutional. Examining Bd. v. Flores de Otero, 426 U.S. 572 (1976) (citizenship requirement not "necessary" to the accomplishment of a legitimate and substantial state purpose held violative of equal protection); In re Griffiths, 413 U.S. 717 (1973); Graham v. Richardson, 403 U.S. 365 (1971).

51. Thirty states provide a role for medical societies in the nomination of board members. GraD app. A, table I.

52. Nineteen states now have lay members. GraD 57, 226 n.14.

53. Most of the boards with lay members have only one or two. Id. 57, 113-14. The profession itself has long opposed lay membership. R. DERBYSHIRE 37.

54. R. DERBYSHIRE 35. 
ing they carry out functions required by state law. ${ }^{55}$

Restraints of trade are nonetheless implicit in the licensing scheme. In particular, the requirement that applicants graduate from approved schools has for many years limited the supply of physicians. State medical boards generally have the power to "approve" medical schools, or to accept the judgment of a national accrediting organization, namely the American Medical Association, the American Osteopathic Association, or the Association of American Medical Colleges. ${ }^{56}$ The limitation of licenses to graduates of approved schools has had its most visible impact in the case of foreign medical graduates (FMGs). ${ }^{57}$

The approval of medical schools represents a classic example of the duality of medical regulation. Competent medical practice is based on physician education in schools that provide sound training, and there is evidence that many FMGs lack such training. However, the limitation of licensure to graduates of approved schools also serves as a limitation on access to the field. Latent xenophobia in the American medical establishment aside, ${ }^{58}$ a desire to limit access may be discerned in the sharp opposition of the AMA and other medical societies to the requirement in the 1976 Health Professions Act ${ }^{59}$ that, as a condition of federal subsidy, medical schools accept American graduates of foreign medical schools so as to enable them to complete their studies and ful-

55. See note 6 supra and text accompanying notes 5-15 supra.

56. GRAD 61 .

57. FMGs presently supply about one-fifth of the medical manpower in this country, though only three-fifths of them are licensed. The rest supply an essential though less highly paid substratum of medical practice under limited or special licenses in public hospitals and other public institutions. For a detailed account of the FMG "problem," see Health Manpower Policies Study Group, School of Public Health, Univ. of Michigan, State Policies on Limited and Temporary Licensure of Foreign Medical Graduates, Contract No. HRA 106-74-68 (1975). See also Dublin, Foreign Physicians: Their Impact on U.S. Health Care, 185 Sclence 407 (1974). On lower test scores of FMGs, see INTERstate AND Foreign CoMmerce Committee, H.R. ReP. No. 266, 94th Cong., 2d Sess. $52-54$ (1976); Weiss, Foreign Medical Graduates and the Medical Underground, 290 NEw ENG. J. MED. 1408 (1974).

The problem of the FMGs, who are generally subject to special license requirements, has come to congressional attention and was dealt with in part in the Health Professions Educational Assistance Act of 1976, Pub. L. No. 94-484, 90 Stat. 2243 (amending the Public Health Service Act, 42 U.S.C. $\$ \$ 201-300$ e-14a (1970 \& Supp. V 1975)), and the Immigration and Nationality Act, 8 U.S.C. $\S \S 1101-1503$ (1970). The law limits FMG entry into the United States to persons who can demonstrate adequate knowledge of English, acceptance for training in a school of medicine and affiliated hospital, and a commitment to return to the country of origin. The limitation on FMG immigration may be waived, however, until December 31, 1980, if its earlier effectuation would result in substantial disruption of health services provided by the medical education program in which the FMG seeks to participate.

58. See, e.g., In re Marburg v. Cole, 286 N.Y. 202, 36 N.E.2d 113 (1941).

59. 42 U.S.C.A. $\$ 295 \mathrm{~g}-2$ (West Supp. 1977) (added by the Health Professions Educational Assistance Act of 1976, Pub. L. No. 94-484, § 782, 90 Stat. 2243, 2314 (1976)). 
fill their educational requirements. ${ }^{60}$ Indeed, several instances have been reported in the press of medical schools announcing that they would forego federal assistance rather than dilute their standards by accepting FMGs. ${ }^{61}$ While AMA opposition to the liberalizing efforts of the 1976 law can hardly be the basis for an antitrust claim-because it is clearly an instance of the first amendment right of petition protected from Sherman Act claims under the Noerr-Pennington doctrine-there is a question whether other efforts of the medical societies to limit the number of medical school graduates are similarly protected. ${ }^{62}$

\section{A. Professional Discipline Under the Medical Practice Acts.}

When a physician has been licensed, he assumes the continuing obligation to comply with the state's medical practice act and with regulations promulgated pursuant to the act by the state medical board. Though the license to practice medicine must be renewed periodically, license renewal has been primarily a revenue measure; a renewal fee is collected, but generally no evidence of continued competence to practice medicine need be shown. ${ }^{63}$ Since the mid-seventies, a growing number of states have adopted continuing medical education requirements, or have authorized their medical practice boards to require continuing education. ${ }^{64}$

The requirements of medical practice laws and regulations differ from state to state but follow fairly regular categories. Though some state laws are very detailed and others quite general, they commonly impose some requirements relating to the physician's continued competence to practice his profession by providing for revocation or suspension of the license or for other sanctions in cases of gross

60. For AMA opposition, see Health Manpower Programs: Hearings on H.R. 2956 Before the Subcomm. on Health and the Environment of the Comm. on Interstate and Foreign Commerce, 94th Cong., 1st Sess. 499, 504, 514 (1975) (statement of Tom E. Nesbitt, M.D.).

61. Eighteen medical schools, including Johns Hopkins, were reported to have rejected government funding so as not to be forced to admit foreign-trained medical students. N.Y. Times, Sept. 6, 1977, at 1, col. 4; N.Y. Times, Aug. 16, 1977, at 18, col. 6.

62. See United States Dental Inst. v. American Ass'n of Orthodontists, 396 F. Supp. 565 (N.D. Ill. 1975).

63. States differ in their requirements in that annual, biennial or triennial license renewals are required, but they uniformly require a renewal fee. GRAD 71.

64. Twenty states mention continuing medical education (CME) in their practice acts; in some the legislature has actually defined and imposed the requirement, while in other states the legislature has either directed or authorized their medical boards to impose such requirements. GRAD 71, $236 \mathrm{n} .95$. In seven states the CME provisions are actually in effect. 1d. 73. Several states have delegated the management of the continuing education programs to medical societies, which will give them a very substantial role in the discipline of the professions when the CME programs become fully operational. See text accompanying note 90 infra. 
incompetence, ${ }^{65}$ and, in a growing number of states, in instances where a physician has become so physically or mentally disabled through old age, drug or alcohol abuse, or from other causes that his continued practice may endanger patients or the general public. ${ }^{66}$ Other requirements deal with such matters as "good moral character" or loss of license for the conviction of a crime, the improper prescription of narcotic drugs, the performance of illegal abortions, the betrayal of professional confidences, or the catch-all offense of "unprofessional conduct," generally interpreted to include some offenses more specifically enumerated in other state laws. ${ }^{67}$ Thus, the "unprofessional conduct" category will include offenses more often referred to in some states as advertising, sharing fees with persons not licensed to practice medicine, aiding and abetting the practice of persons not licensed to practice medicine, and similar offenses which involve not only elements of competence in practice but also aspects of economic control. ${ }^{68}$ These kinds of offenses generally reflect the requirements of the code of ethics of the state or county medical society, and can be-and have been-abused in restraint of trade. ${ }^{69}$

65. Gross incompetence, variously defined, is a basis for discipline in virtually all of the states. The problem is generally not in the precise definition of the term, but rather in finding other physicians willing to testify that a colleague is incompetent. Very few cases based on this ground have been reported. GRAD 125-28.

66. Some thirty-four states have adopted legislation to deal with the disabled physician. The laws generally grant the power to the medical board to require a physician to undergo a physical or mental examination. A variety of probationary remedies and methods for returning the physician to practice are provided for, and in several states the medical society participates in the examination or supervision of a disabled physician. Id. 121-25, 164-68.

67. The offenses in this category are: fraud in obtaining a license, including fraud in application or examination; advertising; fee-splitting; discipline, revocation or suspension of license in another state; violation of medical practice act; betrayal of professional secrets; violating privileged communications; assuring permanent cure for an incurable discease; immorality or gross immorality; misuse of title of M.D. or D.O.; failure to display license; failure to pay annual license fee; making untruthful or exaggerated claims relating to professional excellence or abilities; overcharging. Id. 120-21.

68. $I d$.

69. Gibson v. Berryhill, 411 U.S. 564 (1973) (decided under the Civil Rights Act); Arizona State Bd. of Medical Examiners v. Clark, 97 Ariz. 205, 398 P.2d 908 (1965) (license revocation and loss of society membership based on association with clinic not in good standing because its labor problems allegedly interfered with the free practice of medicine); Blumenthal v. Board of Medical Examiners, 57 Cal. 2d 228, 235-36, 18 Cal. Rptr. 501, 504-05, 368 P.2d 101, 104-05 (1962); Complete Serv. Bureau v. San Diego County Medical Soc'y, 43 Cal. 2d 201, 205, 272 P.2d 497, 499 (1954) (complaint alleging a conspiracy in restraint of trade; the medical society responded with a cross-complaint charging unlawful corporate practice of medicine, aiding and abetting the lay practice of medicine, fee-splitting and solicitation; cross-complaint not only alleged harm to the public health and welfare, but also "an invasion of the property rights of the San Diego County Medical Society and the individual cross-complainants"). See also American Motor Sales Corp. v. New Motor Vehicle Bd., 69 Cal. App. 3d 983, 138 Cal. Rptr. 594 (1977). 
One commentator has observed that until very recently the impact of medical practice acts on assuring medical competence has been minimal. ${ }^{70}$ Record-keeping and documentation of proceedings of state medical boards are generally sparse, ${ }^{71}$ but available evidence indicates that the question of professional incompetence was not involved in most of the very small number of license revocations which did occur. ${ }^{72}$ Professional incompetence is difficult to prove, particularly in light of the continuing reluctance of physicians to testify against fellow physicians. ${ }^{73}$ As a result, though the competence-related requirements of state medical practice acts are clearly sound exercises of the police power to protect the public health and safety-reflecting state action of the kind that renders their application immune from the application of the Sherman $\mathrm{Act}^{74}$ - their minimal enforcement protects the inside group of licensees rather than the public for whose protection the system has professedly been established.

70. While approximately 325,000 physicians in the United States are licensed to practice medicine, for the five-year period from 1968 through 1972 only 1,033 formal disciplinary proceedings occurred. Derbyshire, Medical Ethics and Discipline, 228 J.A.M.A. 59, 61 (1974). Derbyshire, himself a physician, reports on a five-year survey (1968-1972) of forty-seven states-no data were available for the remaining three. The 1,033 actions by medical boards resulted in 297 license revocations, 110 suspensions, 400 probations, 198 reprimands and 28 voluntary surrenders of licenses. According to Derbyshire, fewer than $0.66 \%$ of all physicians had charges brought against them by medical boards over a ten-year period. Id. Derbyshire's figures match the results of a nine-state survey (with only eight states responding) undertaken by this author for the year 1976 . The survey found that what is classified and recorded as a "complaint" varies from state to state. However, even in states with the most complete recording systems, the figures approximate those of Derbyshire. New York had 1,191 complaints over a 16-month period (about 2\% of the physician population) with only 17 dispositions by the medical board and 6 by the Board of Regents. Michigan recorded only 15 complaints with 14 dispositions (about .01\% of the physician population). California received 2,494 complaints and Mississippi reported 7 complaints, but information was not available on dispositions. GRAD app. B at 4-5.

71. Most medical boards have very small staffs and prepare no annual reports. They generally do not keep statistics on the number of complaints by source or nature of the charge, and they just barely keep records of the nature of dispositions. A recent nine-state survey undertaken as part of a study of medical discipline produced evidence of disorganization in the medical board offices, with correspondence remaining unanswered or going astray, but little evidence of activity going back for more than one year. One of the nine states failed to produce any data though prodded and cajoled over a period of almost a year, claiming first that the data were not readily available, and then that there was no staff to dig them out. Id. app. B at 1-3.

72. In seven out of the eight states that responded to this author's nine-state survey, see note 70 supra, drug and alcohol abuse and unlawful drug prescription were the most frequent complaints. In New York, one of the eight states, the most frequent complaint was professional misconduct. In all other states, this was the second most common charge, with complaints of fraud, usually referring to Medicare and Medicaid billing, third. GRAD app. B at 5.

73. Derbyshire, supra note 70, at 60 .

74. For a discussion of the state action exemption, see notes $6,8,10,18,19,21,23$ and text accompanying notes 5-24. 
Medical practice act restrictions on advertising are particularly susceptible to attack on both antitrust and non-antitrust grounds. For example, total restraints on advertising have been invalidated on first amendment grounds in the contexts of fairly standardized legal services, ${ }^{75}$ the sale of drugs and pharmaceuticals, ${ }^{76}$ and the prescription and sale of eyeglasses. ${ }^{77}$ There is no reason why the protection of the first amendment should not extend to appropriately regulated advertising of medical services as well. ${ }^{78}$ Thus, advertising the availability of certain services-such as health maintenance organizations (HMOs) and abortion clinics-has been approved in a number of instances. ${ }^{79}$ Furthermore, restraints on medical advertising are likely to encounter severe Sherman Act attacks. Although the Sherman Act cause of action in Bates was dismissed due to the state action exemption, the broad ban on advertising would clearly have violated antitrust law, just as the bar association minimum fee schedule did in Goldfarb. ${ }^{80}$ This reading of Goldfarb is shared by the Federal Trade Commission, which commenced proceedings against the AMA in 1975, attacking in particular the provision of the AMA Code of Medical Ethics which contains what the FTC has interpreted as an outright prohibition on advertising. ${ }^{81}$ As a private membership organization, the AMA does not share the state immunity of the integrated state bar in Bates.

Other offenses under the state medical practice acts that involve economic constraints are not easy to characterize, because some of them also involve sound elements of patient protection. Some provisions in state medical practice acts that limit and restrain certain of the arguably commercial aspects of the physician's practice relate to the prohibition of fee sharing or of engaging in medical practice with someone not a licensed physician. Cases involving outright fee-splitting

75. Bates v. State Bar of Ariz., 433 U.S. 350 (1977).

76. Virginia State Bd. of Pharmacy v. Virginia Citizens Consumer Council, Inc., 425 U.S. 748 (1976).

77. See, e.g., Rogers v. Friedman, 438 F. Supp. 429 (E.D. Tex. 1977). See also Gibson v. Berryhill, 411 U.S. 564 (1973) (reference to advertising of glasses).

78. See text accompanying notes 13-15 supra.

79. Bigelow v. Virginia, 421 U.S. 809 (1975) (availability of out-of-state abortion services); Abortion Coalition of Mich., Inc. v. Michigan Dep't of Pub. Health, 426 F. Supp. 471 (E.D. Mich. 1977). See also Rogers v. Friedman, 438 F. Supp. 428 (E.D. Tex. 1977) (optometrist advertising); Health Sys. Agency of N. Va. v. Virginia State Bd. of Medicine, 424 F. Supp. 267 (E.D. Va. 1976) (right to provide information to medical directory regarding physicians' fees and services is constitutionally protected); Talsky v. Department of Registration and Educ., 68 Ill. 2d 579, 370 N.E.2d 173 (1977) (chiropractor, advertising ban in the medical practice act); Sterling Optical Co. v. University of the State of N.Y., 55 Misc. 2d 852, 287 N.Y.S.2d 827 (Sup. Ct. 1968).

80. See note 8 supra and text accompanying notes $7 \& 8$ supra.

81. FTC v. American Medical Ass'n, [1973-76 Transfer Binder] TRAde REg. REP. (CCH) I] 21,068 (1975). 
with a runner or agent, or the participation of an untrained or unlicensed person in surgery and other treatment commonly raise little more than police power issues. Both kinds of "sharing" of fees and activites are undesirable because they may hurt patients in situations where the patient cannot protect himself. There may, of course, be marginal cases of physicians allowing highly competent though unlicensed persons to participate in surgery and the like, but in these situations the reach of proper regulatory power rather than significant restraints of trade appears to be involved. Significant issues of restraint of trade are raised, however, when the law is interpreted to ban partnership or group practice arrangements between physicians and such allied health specialists, frequently licensed themselves, as physician's assistants, physiotherapists, occupational therapists, radiation therapists and clinical labatory specialists. As in the case of prohibited advertising, the prohibition is too broad. Perhaps such interdisciplinary arrangements between physicians and other licensed health specialists will require regulation, but there is not likely to be any clear evidence that an outright prohibition protects patients and serves sound police power objectives. ${ }^{82}$

Though such prohibitions have been subject to antitrust challenge when they are part of medical society codes of ethics, they have not been attacked as part of state law or regulation, probably because of the hurdle posed by the Parker state action exemption. ${ }^{83}$ At present, even following Goldfarb and Bates, the anticompetitive impact of a state law is not grounds for its invalidation. The state action exemption, however, is clearly unavailable when the state law lacks any colorable regulatory purpose and is the result of a conspiracy to abuse the legislative process. ${ }^{84}$ Thus, California Motor Transport Co. v. Trucking Unlimited, ${ }^{85}$ which interpreted the Noerr-Pennington doctrine, held that "[c]onspiracy with a licensing authority to eliminate a competitor may also result in an antitrust transgression."

82. Although the author is unaware of any successful challenges to fee-splitting provisions on antitrust grounds, the justifications given to support these provisions are hardly more weighty than those considered in Goldfarb. For a cross-section of justifications on this point, see Magan Medical Clinic v. California State Bd. of Medical Examiners, 249 Cal. App. 2d 124, 57 Cal. Rptr. 256 (1967); Complete Serv. Bureau v. San Diego County Medical Soc'y, 43 Cal. 2d 201, 272 P.2d 497 (1954); Texas State Bd. of Examiners in Optometry v. Carp, 412 S.W.2d 307 (Tex.), application for writ of error dismissed for want of jurisdiction, 389 U.S. 52 (1967).

83. See text accompanying notes 5-24 supra.

84. Handler, The Current Attack on the Parker v. Brown State Action Doctrine, supra note 4, at 3-7.

85. 404 U.S. 508 (1972).

86. Id. at 513 . 
Berryhill, ${ }^{87}$ the Supreme Court found that an optometrist whose license was revoked had been denied due process because all the members of the state licensing board were optometrists in competition with the plaintiff who had pecuniary interests in the outcome of the case. The relevance of these decisions to the field of medical discipline is obvious-medical boards composed primarily of physicians sit in judgment of other physicians with whom they often compete. It is clear that even sound regulations may be applied in an abusive and anticompetitive fashion..$^{88}$

The state regulatory system of medical discipline has a number of formal and informal links with the self-administered system of professional discipline operated by the state and county medical societies. As noted earlier, the medical practice acts and regulations generally reflect, and to some extent duplicate, the codes of professional ethics adopted by private medical societies. In addition, state laws frequently require that the governor appoint the members of the state medical board from lists submitted by the medical societies. ${ }^{89}$ Under many of the state laws, the medical societies are also delegated a variety of functions. In some jurisdictions, the medical societies are delegated the task of operating the continuing medical education program..$^{90}$ Failure to complete the necessary educational requirements before the time set for license renewal may result in the refusal to renew a physician's license. The medical society's role in the continuing education program provides another opportunity for abuse; the society can refuse to renew the license of a physician who has not followed the medical society's poli-

87. 411 U.S. 564 (1973).

88. One such instance of abuse may be cited. Although medical license laws have many very similar requirements and call for the taking of national licensing examinations, reciprocity, though provided for, is not granted by every state. It is frequently said, though no case law substantiation is available, that the "sunshine belt" states do not extend reciprocity to physicians from other parts of the country, and that they apply their otherwise sound licensing laws so as to bar new competitors wishing to establish practices within the state. The targets of the ban are seasoned practitioners from other parts of the country with less pleasant climates who wish to spend their waning years as part-time or semi-retired practitioners in desirable locations, competing with long-time resident physicians. It would take considerable study of past records-which are not likely to be available- to establish such a pattern of anticompetitive behavior. See, e.g., Mann v. Board of Medical Examiners, 31 Cal.'2d 30, 187 P.2d 1 (1947).

89. See note 51 supra and accompanying text.

90. See, e.g., ARIZ. REv. STAT. § 32-1429(H) (Supp. 1977-78) (requiring program to be certified by a medical society or college or university); N.M. STAT. ANN. § 67-5-3(E) (1961) (program must reflect "consensus of the medical community"); OHro REv. CODE ANN. \& 4731.281 (Page 1977); R.I. Gen. LAws \& 5-37-2.1 (Cum. Supp. 1977). See also AMA Council on Health Manpower, Continuing Competence of Physicians, 217 J.A.M.A. 1537 (1971) ("The AMA Council on Medical Education, with its Advisory Committee on Continuing Medical Education, is responsible for the codification, review, and accreditation of continuing education programs for physicians." Id. 1537.) 
cies by alleging that he has failed to meet the continuing medical education requirements. Although the opportunity for abuse does exist, no cases challenging the delegation of authority to the medical society, or charging abuses of that authority, had been reported by late 1977 .

Another link between the state board and the medical societies is the role medical societies play in official disciplinary procedures. In thirteen states, the medical societies are required by law to report to the state board that a physician has been the subject of a medical society disciplinary proceeding. ${ }^{91}$ Depending on the nature of the charge and the circumstances, the matter may be investigated by the state board which may then proceed to base an official state disciplinary proceeding on the facts disclosed. A few states have gone so far as to delegate the investigation of complaints of violations of their medical practice acts to their respective state medical societies, ${ }^{92}$ and one state has actually delegated the entire state medical disciplinary function to the medical society. ${ }^{93}$

Another area in which state and county medical societies play a significant role is in the control and rehabilitation of physicians who, by reason of physical or mental illness, old age or drug abuse, including alcoholism, may create health and safety hazards if permitted to practice. Under so-called "sick physicians acts" adopted in the majority of states, provision is made for a variety of rehabilitative efforts, including both suspension of the license until full capacity to practice has been demonstrated, and probation, which may involve limitation of the license to practice or limitation to practice under supervision. ${ }^{94}$ In some states, the medical societies play an important role in the probationary effort, providing the necessary supervision and taking a part in the process of determining that a physician is again capable of returning to full and unsupervised practice. ${ }^{95}$

The development of PSROs adds another significant element to the close relationship between the official regulatory boards and the private medical societies in the management of professional conduct. ${ }^{96}$

91. Grad 204, 272 n.546, app. A, table III.

92. Conn. Gen. Stat. Ann. § 20-13e(a) (West Supp. 1978); Ky. Rev. Stat. § 311.595(2) (1969); Md. ANN. CODE art. 43, § 130(g) (1971). See also NEB. Rev. STAT. $§ 44-2848$ to 2851 (Cum. Supp. 1976).

93. In Alabama, the Board of Censors of the State Medical Association sits as the Board of Medical Examiners. AlA. CODE \& 34-24-53 (1975).

94. See, e.g., Fla. STAT. ANN. \$ 458.1201 (West Supp. 1978); N.Y. Educ. Law $\$ 6511$ (McKinney Supp. 1977-78); PA. STAT. ANN. tit. 63, $\S 421.15(\mathrm{~b})(4)$ (Purdon Supp. 1978-79). See also GRAD 182, 186-87.

95. See, e.g., Miss. Code ANN. \$73-25-55(2) (Cum. Supp. 1977); N.M. STAT. ANN. \$§ 67-424, 67-42-7(A) (Interim Supp. 1976); OR. Rev. StaT. \$§ 677.415(2), 677.420(4) (1977).

96. See text accompanying notes 147-76 infra. 
This closeness provides a setting for abuse. Although there are only a few reported instances of the manipulation of state agencies to limit competition or to exile from the profession persons who have violated the private society's code, they indicate that such abuses can occur and may well be more prevalent than is apparent. ${ }^{97}$

The interrelationship of state regulatory agencies and professional organizations may become more significant in light of recent Supreme Court decisions. In both Bates and Virginia Board of Pharmacy, the Court placed heavy emphasis on the capabilities of regulatory agencies and professional self-discipline to prevent abuse that may result from greater competition. ${ }^{98}$ In the future, many of the anticompetitive restraints imposed on the learned professions, either by regulatory agencies or by professional societies, which have some stabilizing effect on the standards of the professions may be held illegal under the antitrust laws. The Supreme Court assumes that the benefits to be gained by removing anticompetitive restraints will not adversely affect professional performance because state agencies and professional societies will enforce proper professional standards. Thus, the decisions that purport to create a freer market implicitly support more regulation. As the restraints on competition are abolished by antitrust enforcement, the stabilizing effects these restraints may have had on professional performance will have to be replaced by more state regulation to protect the patient, client or other consumer of professional services. Therefore, a likely result of increased antitrust activity is a concomitant increase in the level of state regulation to insure that a high caliber of professional service is maintained. The opinions in Goldfarb and Bates both concluded by reminding the states that these decisions did not affect the states' right to regulate the learned professions. This suggests that the Court realized that increased state regulation might be necessary to offset any detriment that might be caused by abusive professional competition.

\section{B. Professional Self-Discipline Administered by Medical Societies.}

The strong influence of the professional organizations in the disciplinary scheme is already evident in roles they play in the state regulatory scheme. The great and dominant national medical society is the

97. See, e.g., Arizona State Bd. of Medical Examiners v. Clark, 97 Ariz. 205, 398 P.2d 908 (1965); Feminist Women's Health Center, Inc. v. Mohammad, 415 F. Supp. 1258 (1976). See also Gibson v. Berryhill, 411 U.S. 564 (1973); Sterling Optical Co. v. University of the State of N.Y., 55 Misc. 2d 852, 287 N.Y.S.2d 827 (Sup. Ct. 1968); State Bd. of Osteopathic Examiners v. Berberian, 200 Pa. Super. Ct. 533, 190 A.2d 330 (1963); Harang v. Aetna Life Ins. Co., 400 S.W.2d 810 (Tex. Civ. App. 1966).

98. See text accompanying notes $35-42$ supra. 
American Medical Association, probably one of the most influential special-interest groups in the nation. Its membership numbers 203,000 out of a total of some 325,000 practicing physicians in the country. ${ }^{99}$ As the primary spokesman for the medical profession, it has sought to protect the financial interests of its members by affecting the shape of medical and public health legislation throughout the nation. A generally conservative organization, it opposed Medicaid and Medicare legislation and acquiesced in it only when the expensive fee-for-service approach, rather than a capitation approach, was written into the law. ${ }^{100}$ It long opposed Health Maintenance Organization (HMO) legislation and acquiesced in it only when fairly onerous conditions were imposed on HMOs and when it became apparent the HMO legislation would be a good device to postpone the consideration of national health insurance. ${ }^{101}$ Most recently, the AMA opposed major provisions of the Health Professions Education Assistance Act of $1976,{ }^{102}$ particularly provisions which would have required physicians educated with federal assistance to serve for a period of time in parts of the nation that experience physician shortages. ${ }^{103}$ The AMA also opposed adoption of the PSRO legislation until the influence of the state medical societies was assured. ${ }^{104}$

The AMA, as the voice of organized medicine, is represented on virtually all of the boards and governing bodies of the national societies that have an interest in medical licensure or the regulation of medical practice, including the Federation of State Medical Boards, an organization that reflects the interests of all state medical licensing agencies. One of the most important roles played by the AMA is its membership, together with the American Hospital Association, on the Joint Commission on the Accreditation of Hospitals (JCAH). ${ }^{105}$ As a JCAH

99. Information provided by a member of the Membership Development Office of the AMA, Chicago, Illinois (telephone interview, May 1978).

100. For a contemporary account of AMA opposition to Medicare, see M. GReENFIELD, Health Insurance For the Aged: The 1965 Program for Medicare 95-100 (1966). See also M. Greenfield, Medicare and Medicaid: The 1965 and 1967 Soclal Security AmendMENTS 77-104 (1968).

101. See, e.g., Hearings on Health Maintenance Organization Amendments Before the Sub. comm. on Health of the Senate Comm. on Labor and Public Welfare, 94th Cong., 1st \& 2d Sess. 578-89 (1975-76) (statement of Edgar T. Beddington, Jr., M.D.).

102. Pub. L. No. 94-484, 90 Stat. 1945 (1976).

103. See Hearings on Health Manpower Programs Before the Subcomm. on Health and the Environment of the House Comm. on Interstate and Foreign Commerce, 94th Cong., 1st Sess. 499524 (1975) (statement of Tom E. Nesbitt, M.D.).

104. See Hearings on the Implementation of PSRO Legislation Before the Subcomm. on Health of the Senate Comm. on Finance, 93d Cong., 2d Sess. $59-82$ (Pt. 1) (1974) (statement of Russel Roth, M.D.).

105. See text accompanying notes 117-18 infra. 
member, the AMA exercises major influence over the standards and services of hospitals in the nation. This influence also affects specialization training. In order to qualify in specialty areas, a physician must obtain such training in "accredited" hospitals, i.e., hospitals accredited by the JCAH, in a residency program accredited by the Liaison Committee on Graduate Medical Education, which is composed of representatives of the AMA, the American Hospital Association, the American Board of Medical Specialties, the Association of American Medical Colleges and the Council on Medical Specialty Societies. ${ }^{106}$

The AMA is regarded as the parent organization of all state medical societies, and through them, of all county medical societies. The Code of Medical Ethics adopted by the AMA is the code followed by state societies. Although the AMA provides its members and its constituent organizations with a great deal of information and advice on professional disciplinary matters, it does not involve itself directly in disciplinary proceedings, thus leaving each state and county society to operate its own disciplinary mechanism.

State and county medical societies generally apply the AMA Code of Professional Ethics, including its ban on advertising and its ban on practicing with persons not licensed to practice medicine. Although organized medicine, like other professions, resists external regulation by government agencies by asserting that a learned profession is capable of policing itself, very little evidence suggests that it does. While statistics on the activities of state medical boards are slight and unimpressive, ${ }^{107}$ national statistics on professional self-discipline by medical societies are virtually non-existent. ${ }^{108}$

Although in many states professional discipline by medical societies must be reported to the state medical board and may trigger official action, professional discipline administered by medical societies themselves is necessarily very limited in scope and in sanctions. In general, medical societies are limited to dealing with the professional discipline of their own members, and the heaviest sanction that a society can impose is suspension or termination of membership. The sanction has a different impact in different parts of the country. In large metropolitan settings, ouster from the county medical society, though professionally harmful, is far less damaging than a similar sanction imposed in a

106. Llaison Comm. on Graduate Medical Educ., supra note 49, at 5, 7.

107. See note 71 supra and accompanying text.

108. Derbyshire, supra note 70 , at 60 . The most recent figures available are for 1968 , when thirty-three state medical societies reported no disciplinary procedures at all. For several years, the AMA requested that medical societies report disciplinary actions but the project was terminated in 1969 by the AMA Department of Medical Ethics which considered it "a waste of time." Id. 
small town or semi-rural setting with few physicians and a single small hospital to serve the community. In such a setting, the sanction has long carried with it a measure of professional ostracism and probably a loss of staff privileges at the local hospital. The impact of ouster from the medical society is primarily economic, since both association with other physicians and the privilege to place patients in the local hospital are necessary to conduct a full medical practice. ${ }^{109}$ Because of this effect on state-licensed professionals, medical society disciplinary proceedings have sometimes been characterized as "state action" for procedural purposes, requiring the full panoply of procedural due process. At a minimum, even when not regarded as state action, the potential impact on the physician's practice of disciplinary proceedings has caused courts to require at least an unbiased panel and a full measure of fairness in the proceedings. ${ }^{10}$

Anticompetitive aspects of the AMA-sponsored code of professional ethics have long provided the basis for antitrust litigation. In American Medical Association v. United States, ${ }^{111}$ the Supreme Court upheld the conviction of the AMA and others for conspiring to violate the Sherman Act. The defendants were convicted of obstructing the operation of a prepaid medical care and hospitalization plan, Group Health Association, Inc. The plan had hired physicians and contracted for hospital facilities, in violation of the associational and independent practice provisions of the code of ethics. The AMA and the other defendants had, in pursuance of the code of ethics, dissuaded physicians

109. See, e.g., Pinsker v. Pacific Coast Soc'y of Orthodontists, 1 Cal. 3d 160, 165-67, 81 Cal. Rptr. 623, 626-27, 460 P.2d 495, $498-99$ (1969). See also Ascherman v. San Francisco Medical Soc'y, 39 Cal. App. 3d 623, 636-37, 114 Cal. Rptr. 681, 688-89 (1974); Westlake Community Hosp. v. Superior Court of Los Angeles County, 17 Cal. 3d 465, 131 Cal. Rptr. 90, 551 P.2d 410 (1976). The leading and most frequently cited case on the subject of impact of medical society membership on hospital affiliation is Falcone v. Middlesex County Medical Soc'y, 34 N.J. 582, 170 A.2d 791 (1961), in which a highly qualified osteopathic physician, though fully licensed, was denied membership in the local medical society without adequate explanation and subsequently was deprived of hospital privileges. The court's assistance was also successfully sought in another, factually similar case, Kurk v. Medical Soc'y of the County of Queens, Inc., 46 Misc. 2d 790 (Sup. Ct. 1965). However, some courts have refused to intervene when there was no showing of a formal relationship between hospital privileges and membership in the medical society or evidence of medical society control of access to hospital privileges, or where there was no showing of economic necessity for judicial intervention. See e.g., Pima County Medical Soc'y v. Felland, 115 Ariz. 311, 565 P.2d 188 (Ct. App. 1977); Maricopa County Medical Soc'y v. Blende, 5 Ariz. App. 454, 427 P.2d 946 (1967); Schooler v. Tarrant County Medical Soc'y, 457 S.W.2d 644 (Tex. 1970).

110. In re Smith, 10 Wend. 449 (N.Y. 1833); Glauber v. Patof, 183 Misc. 400,47 N.Y.S.2d 762 (1944). See also Pinsker v. Pacific Coast Soc'y of Orthodontists, 12 Cal. 3d 541, 526 P.2d 253, 116 Cal. Rptr. 245 (1974); Ascherman v. San Francisco Medical Soc'y, 39 Cal. App. 3d 623, 114 Cal. Rptr. 681 (1974); Fried v. Straussman, 82 Misc. 2d 121 (Sup. Ct. 1975).

111. 317 U.S. 519 (1943). 
from accepting employment with the health care plan and from providing it with consulting services.

Because the AMA case was brought under section 3 of the Sherman Act which prohibits anticompetitive conduct in the District of Columbia, its applicability was regarded as limited for some time, and few actions of a similar nature were brought prior to Goldfarb. The finding in Goldfarb that a state minimum fee schedule affected interstate commerce opened up much of the field of medical regulation to potential federal antitrust prosecution.

Other limitations of an associational and economic nature have been dealt with in the courts. Requiring membership in a national professional association as a condition of admission to the local professional association (which provided the practitioner with important services and information) was found to be an anticompetitive tying arrangement in violation of the Sherman Act, where no benefit to the public results from such an arrangement. ${ }^{112}$ It might be added that the closely interlocking arrangements of organized medicine may well raise questions analogous to those raised in Associated Press v. United States, ${ }^{113}$ where organizational arrangements themselves gave rise to antitrust liability. The bylaws of the Associated Press prohibited selling news to non-members, and each member had the right to block from membership any non-member competitor. As the dissent pointed out, there was no evidence that Associated Press had a monopoly, dominated the field, fixed prices or engaged in coercive or other predatory practices. However, the nature of the bylaws and the organizational structure itself was, in the opinion of the majority, sufficient to constitute a restraint of trade. Similar considerations might well apply to local medical societies that require membership in national societies or exercise control over hospital affiliations, thus limiting the source or market for their members' purchase or sale of services.

\section{Medical Self-Discipline in the Hospital.}

The system of discipline imposed on physicians by the hospitals in which they practice also has important consequences. There was less concern over the physician's performance when hospitals were immune from suit by reason of governmental or charitable immunities. ${ }^{114}$ Then, too, prior to the decision in Darling v. Charleston Community Memorial

112. Boddicker v. Arizona State Dental Ass'n, 549 F.2d 626 (9th Cir.), cert. denied, 434 U.S. 825 (1977).

113. 326 U.S. 1 (1945).

114. See generally W. Prosser, The LAW of TorTs 980 n.96, 993 n.32 (4th ed. 1971). 
Hospital, ${ }^{115}$ physicians practicing within a hospital were generally regarded as independent contractors, and no responsibility for their professional mistakes devolved upon the hospital. ${ }^{116}$ With the advent of hospital liability, however, hospitals have assumed responsibility for the care of the patient. In consequence, they began to pay considerably greater attention to physician performance within the hospital and to adopt systems of peer review and medical discipline which had in earlier days been limited largely to teaching hospitals.

Another source of physician discipline within hospitals is the set of standards of the JCAH which began to include requirements for review of the physician's practice within the hospital in 1965, after the enactment of the Medicaid and Medicare law which set requirements for "participating hospitals." These requirements could be met either by having a state certifying agency certify substantial compliance, or by relying on the provision of the federal law that "an institution shall be deemed to meet the requirements . . . if such institution is accredited as a hospital by the Joint Commission on the Accreditation of Hospitals." 117 This provision had the effect of moving JCAH accreditation into new areas covered by federal law, including such matters as the quality of the services within the hospital and aspects of utilization review. ${ }^{118}$

Because hospitals are now responsible and liable for the performance of the physicians within institutions, they must exercise great care in selecting physicians for employment and in extending staff privileges to physicians for the treatment of private patients. Consequently, great care may be taken by the medical staff in evaluating a physician's education and experience before granting privileges. Often only limited privileges are granted during a period of probation, and even when a physician obtains full privileges he is subject to staff rules on consultation, his records may be reviewed periodically and his patients may be included in clinical rounds. If a physician's professional work does not meet minimum standards, privileges may be denied at the outset, denied renewal or revoked. ${ }^{119}$ The non-renewal or revocation of privi-

115. 33 Ill. 2d 326, 211 N.E.2d 253 (1965), cert. denied, 383 U.S. 946 (1966).

116. See, e.g., Barfield v. South Highlands Infirmary, 191 Ala. 553, 559, 68 So. 30, 33 (1915); Iterman v. Baker, 214 Ind. 308, 318, 15 N.E.2d 365, 370 (1938). It should be noted that the independent contractor doctrine had earlier been applied both to employed staff physicians and to attending physicians who had been granted "privileges" at the hospital to treat their own patients.

117. 42 U.S.C. $§ 1395 b b$ (1970).

118. See generally Joint Commission on Accreditation of Hospitals, Program of HosPITAL ACCREDITATION STANDARDS OV 7-8 (1976).

119. The physician's performance within the hospital is generally subject to review by medical staff committees, such as medical audit committees that review patient records for compliance with standards, C. EISELE, The Medical STAFF IN THE MODERN Hospital 180 (1967), and tissue 
leges may have far-reaching consequences for a physician, because no other hospital in the area is likely to grant him privileges either, and his record may follow him elsewhere if he tries to relocate.

Because of their great professional importance to physicians, with regard to both professional standards and economic impact on earnings, hospital privileges enjoy substantial legal protection. Under JCAH recommendations, privileges are not to be denied or revoked without a hearing, usually before the governing board of the hospital, and staff bylaws must be adopted and followed where applicable. ${ }^{120}$ Since governing boards usually consist of laymen, members are not likely to question the judgment of medical staff committees; hence review boards are not likely to provide great protection to a physician whose competence has been disapproved by his medical colleagues. The issue of the "right" to staff privileges has increasingly occupied the courts since the late sixties, ${ }^{121}$ and has become the subject of some state legislation. ${ }^{122}$

committees that supervise the necessity for, and the quality of, surgery, Joint Commission on Accreditation of Hospitals, Bull. 21, Tissue Committee of a Hospital Medical Siaff (1959). For a case upholding revocation or suspension of privileges for inadequate medical performance, see Peterson v. Tucson Gen. Hosp., 114 Ariz. 66, 559 P.2d 186 (1977).

120. See JoInt Commission on ACCReditation of Hospitals, ACcreditation Manual FOR HoSPITALS 81-82 (1976).

121. Although the privilege against unreasonable, arbitrary, capricious or discriminatory denial or revocation has long enjoyed protection in public hospitals, see, e.g., Ware v. Benedikt, 225 Ark. 185, 187-88, 280 S.W.2d 234, 236 (1955); Milford v. People's Community Hosp. Auth., 380 Mich. 49, 57, 155 N.W.2d 835, $841-42$ (1968), it is now fully recognized in private hospitals as well, with judicial recognition of the fact that private hospitals serve particular communities under public charter and operate increasingly with public money. They are generally regarded, therefore, as engaged in "state action." See, e.g., Blank v. Palo Alto-Stanford Hosp. Center, 234 Cal. App. 2d 377, 44 Cal. Rptr. 572 (1965); Silver v. Castle Memorial Hosp., 53 Haw. 475, 497 P.2d 564, cert. denied, 409 U.S. 1048 (1972); McElhinney v. William Booth Memorial Hosp., 544 S.W.2d 216 (Sup. Ct. Ky. 1976); Sussman v. Overlook Hosp. Ass'n, 95 N.J. Super. 418, 231 A.2d 389 (1967); Greisman v. Newcomb Hosp., 76 N.J. Super. 149, 183 A.2d 878 (L. Div. 1962), affd, 40 N.J. 389, 192 A.2d 817 (1963); Davidson v. Youngstown Hosp. Ass'n, 19 Ohio App. 2d 246, 48 Ohio Ops. 2d 371, 250 N.E.2d 892 (1969). But see Davis v. Morristown Memorial Hosp., 106 N.J. Super. 33, 254 A.2d 125 (1969) (private hospital's policy of no staff obstetricians and gynecologists held valid); Woodard v. Porter Hosp., Inc., 125 Vt. 419, 217 A.2d 37 (1966) ("authorities of a private hospital are vested with broad discretionary powers in the selection of its medical and surgical staff" 217 A.2d at 40).

122. See, e.g., IND. Code ANN.\$ 16-12.1-5-1 (Burns 1973) (hospitals must have reasonable regulations and cannot discriminate among schools of medicine); LA. REv. STAT. ANN. § 37:1301 (West 1974) (nonprofit hospitals may not discriminate against physicians who participate in medical group practice, may not require membership in a specialty body or medical society as prerequisite to the granting of staff privileges); N.M. STAT. ANN. \& 67-8-12 (1974) (protection of the rights of osteopathic surgeons); N.Y. PUB. HEALTH LAW \& 206-a (Consol. 1976) (protection of those physicians involved in medical group practice and nonprofit health insurance plans); OR. REV. STAT. tit. 36, \& 441.077 (1977) (hospitals cannot discriminate among schools of medicine under penalty of revocation of license); S.D. CoMPILED LAws ANN.\$ 34-8-8 (1977) (county hospitals cannot discriminate among schools of medicine). 
In dealing with actions to review the denial or loss of staff privileges, courts generally have required that the physician be given the due process requirements of notice and hearing and be judged by rational and reasonable standards. Standards must be limited to matters of professional competence, and vague, unrelated requirements that are subject to abuse will be invalidated. For example, a requirement that staff members be "temperamentally and psychologically suited for cooperative staff hospital functions" has been rejected. ${ }^{123}$

Physicians who had lost or been denied the renewal of staff privileges were able, in the past, to relocate and continue their incompetent practice elsewhere. Hospitals, too, were often willing to allow a physician to resign voluntarily to avoid going through the trouble of a formal revocation proceeding. To prevent incompetent physicians from continuing in practice by changing hospital affiliations, state medical practice acts in a growing number of states now require hospitals to report to the medical board whenever disciplinary action is taken, particularly when hospital privileges are revoked or limited, thus providing an opportunity to use hospital disciplinary action as a device to trigger investigation by the state board..$^{124}$

While the system of medical discipline in the hospital is most important for patient protection, it is potentially subject to abuse precisely because it has such far-reaching consequences on a physician's career and livelihood. In areas where the local medical society and the staff of the only hospital in the community are closely interlocked, it will be impossible for a physician to run counter to the established medical interests unless he is prepared to take the matter to court. While legal protections may prevent the arbitrary denial of staff privileges, the practical considerations are likely to dictate a physician's professional conduct. There is at least some evidence that local medical societies use the physician's fear of losing hospital privileges as a device to pressure him and to prevent him from providing services in other institutions

123. Rosner v. Eden Township Hosp. Dist., 58 Cal. 2d 592, 375 P.2d 431, 25 Cal. Rptr. 551 (1962). See also Ascherman v. San Francisco Medical Soc'y, 39 Cal. App. 3d 623, 114 Cal. Rptr. 681 (1974). In Ascherman, an apparently highly qualified surgeon was simultaneously deprived of privileges at five hospitals. No charges relating to his competence were raised, but questions were raised within the medical society relating to his professional conduct and judgment after he had taken a stand in favor of Medicare and had expressed strong opposition to the posture of the American Society of Internal Medicine on the subject. The court found that the hospitals had acted improperly in depriving the surgeon of privileges without explanation, but somewhat unaccountably failed to find evidence of a conspiracy-though the loss of privileges at all of the hospitals was virtually simultaneous. Sound grounds for refusing to grant privileges will be upheld, however, such as a failure by the physician seeking privileges to have completed an AMA-approved internship. Fritz v. Huntington Hosp., 48 App. Div. 2d 684, 367 N.Y.S. 2d 847 (1975).

124. GRAD 225, 227 n.614. 
not favored by the society. ${ }^{125}$ Of the relatively few court cases challenging the loss of hospital privileges, most arose in small communities where both medical societies and hospitals were involved in situations raising questions of economic boycott. ${ }^{126}$

\section{Medical Discipline and Medical Specialties: Specialty Boards.}

Modern medical practice is characterized by specialization, but unlike medical licensure for the practice of medicine generally, specialty certification is controlled by specialty boards. These boards are private, nonprofit organizations without any governmental authority. By controlling access to an increasingly important part of the medical profession, the specialty boards wield significant power. ${ }^{127}$

There are at present twenty-two specialty boards which establish standards and control certification for their respective specialties. ${ }^{128}$ The work of these boards is coordinated by the American Board of Medical Specialties (ABMS), which seeks to prevent duplication of activities among the boards, recognizes new specialty boards, speaks for the interests of medical specialty boards generally and serves as a control organization for the consideration of self-regulation of specialty practice.

125. See, e.g., Feminist Women's Health Center, Inc. v. Mohammad, 415 F. Supp. 1258, 126667 (N.D. Fla. 1976).

126. See note 109 supra and accompanying text.

127. Though in $1975-76$ only $46 \%$ of physicians not in training included in the national registry of physicians (maintained by AMA) were diplomates of a specialty board, the recent trend is for most medical graduates to seek specialty training. AMERICAN BoARd of MEDICAL SPECIALTIES, ANNUAL REPORT 1975-76, at 22.

128. American Board of Allergy and Immunology, Policies and Procedures (1977); AMERICAN BOARD OF ANESTHESIOLOGY, INC., BOOKLET OF INFORMATION (1977); AMERICAN BOARD OF COLON AND RECTAL SURGERY, INC., GENERAL INFORMATION (July 1977); AMERICAN BOARD OF DERMATOLOGY, INC., BOOKLET OF INFORMATION (1976); AMERICAN BOARD OF FAMIIY PRACTICE, GENeral INFormation (1978); AMERICAN Board of InTERnal MEdicine, POLicies and Procedures (July 1976); American Board of Neurological Surgery, INC., BOoKLEt OF INFormation (Mar. 1, 1977); AMERICAN BoARd of NuClear MEDiCine, INC., INformation, Policies and Procedures (1977); AMerican BoArd of Obstetrics and GYNeCOLOGY, INC., BULLETIN FOR 1977 (Aug. 1976); AMERICAN BOARD OF ORTHOPOEDIC SUROERY, INC., Rules AND PROCedures (1977); AMerican BoARd of Otolaryngology, BoOKLEt of INFORMATION (Jan. 1977); AMERICAN BOARD OF PEDIATRICS, INC., BOOKLET OF INFORMATION (July 1, 1976); American Board of Physical Medicine and Remabilitation, Booklet of INFORMATION (1976); AMERICAN BOARD OF PLASTIC SURGERY, INC., BOOKLET OF INFORMATION (1976-77); American Board of Preventative Medicine, Inc., Bulletin(13th ed. 1976);

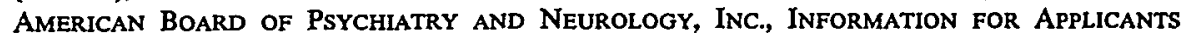
(Nov. 1, 1975); AMERICAN BOARD OF RADIOLOGY, BOOKLET OF INFORMATION (1977); AMERICAN BOARD OF SURGERY, INC., BOOKLET OF INFORMATION (JUly 1, 1976); AMERICAN BOARD OF THORACIC SURGERY, INC., BOOKLET OF INFORMATION (Jan. 1977); AMERICAN BOARD OF UROLOGY, INC., CANDIDATES' INFormation (24th ed. 1977). 
Board certification gives a physician both privileges and liabilities. It provides greater professional status and the economic benefits of increased patient referrals and easier access to hospital privileges. It also subjects physicians to higher standards of practice applicable to the particular specialties. ${ }^{129}$

The primary function of most specialty boards has been to provide credentials and to certify physicians in specialties by administering an examination and reviewing the completion of residency requirements. All specialty boards require that a candidate complete an approved residency in his specialty. Residencies are approved by the Liaison Committee on Graduate Medical Education of the American Medical Association. The examination of specialties follows the "Essentials for Approval of Examining Boards in Medical Specialties"-guidelines which are issued jointly by the American Board of Medical Specialties and the AMA Council on Medical Education, through its Liaison Committee for Specialty Boards. ${ }^{130}$ Thus, the AMA is significantly involved in all phases of specialty certification.

Specialty certification requirements place considerable stress on thorough clinical training; the length of residency required varies from three to five years of post-medical school training. In addition, some boards require further periods of practice in the specialty, ranging from six months to two years, following the completion of the residency. ${ }^{131}$ In most specialties, however, an applicant becomes eligible to take the certification examination when he finishes his residency. In addition to the written examination, fifteen specialty boards require an oral or practical examination, or both. ${ }^{132}$

The certification process appears to be a valuable and thorough method of qualifying specialists. Once a specialist has been certified, however, most specialty boards are not involved with assuring continued competence. Though grounds for revocation of certificates exist, few have ever been revoked; the grounds are generally limited to misrepresentations or failures to make appropriate disclosures in the origi-

129. For an excellent discussion of the certification process see Wallace, supra note 4.

130. Liaison Comm. on Graduate Medical EduC., supra note 49, at 367-434.

131. This additional practice period is required by the American Boards of Neurological Surgery, Obstetrics and Gynecology, Orthopedic Surgery, Plastic Surgery and Urology. GRaD 88, 243 n.157.

132. The Boards requiring an oral examination are: Anesthesiology; Colon and Rectal Surgery; Dermatology; Neurological Surgery; Obstetrics and Gynecology; Ophthalmology; Otolaryngology; Pediatrics; Physical Medicine and Rehabilitation; Plastic Surgery; Psychiatry and Neurology; Radiology; Surgery; Thoracic Surgery; Urology. Note also that the American Board of Internal Medicine requires an oral examination only for its subspecialty board on cardiovascular disease. Id. 89, 243 n.is9. 
nal application-situations in which the certificate would not have been issued in the first instance had the full facts been known. Some boards provide for revocation of the certificate when a physician's license is revoked, ${ }^{133}$ and several provide for revocation upon conviction of a felony or serious misdemeanor. ${ }^{134}$ Two boards list suspension or expulsion from a medical society as grounds for revocation, ${ }^{135}$ and several boards include as grounds failure to maintain moral, ethical or professional standards. ${ }^{136}$ Only two boards, Family Practice and Urology, mention incompetence as a ground for revocation. ${ }^{137}$ There appears to be a growing concern over the maintenance of competency, however, because eleven of the twenty-two boards have taken some action toward the development of a recertification program, and some others have endorsed the concept. ${ }^{138}$

The process of specialty certification, and the role of the specialty boards in the process, are entirely self-contained, without any governmental input. While in theory the boards do not control specialty practice because as a matter of law any physician can practice in any specialty area, in fact the situation is different. As both an economic matter and a matter of professional standing, board certification is enormously important; otherwise it would not be sought after so frequently and energetically. Moreover, many state laws require board certification for a physician to provide certain services, ${ }^{139}$ and, although

133. Those providing for such revocation are the American Boards of Dermatology, Orthopedic Surgery, Otolaryngology, Preventive Medicine, Psychiatry and Neurology, Radiology, Thoracic Surgery and Urology. Id. 92, 244 n.171.

134. Those providing for such revocation are the American Boards of Dermatology, Otolaryngology, Radiology, and Thoracic Surgery. Id. 92, 244 n.172.

135. The American Boards of Ophthalmology and Obstetrics and Gynecology list suspension from a local, regional or national organization of professional peers as evidence of a violation of standards of ethical practice, one of the grounds for revocation of a certificate. Id. 92, 244 n.173.

136. The American Boards of Anesthesiology, Obstetrics and Gynecology, and Urology. Id. 92,244 n. 174.

137. Id. 92, 244 n.175, 245 n.176.

138. Eleven of the twenty-two boards have indicated in their literature that they have taken some action towards recertification: American Boards of Allergy and Immunology, Colon and Rectal Surgery, Family Practice, Internal Medicine, Neurological Surgery, Nuclear Medicine, Ophthalmology, Otolaryngology, Preventive Medicine, Surgery and Thoracic Surgery. Three boards have actually initiated mandatory recertification programs: Family Practice, Surgery and Thoracic Surgery. Three boards have instituted voluntary recertification programs: Allergy and Immunology, Internal Medicine and Ophthalmology. The others are still in the planning stages. See generally Id. 92-96; authorities cited at note 128 supra.

139. See, e.g., N.Y. PuB. Health Law \& 3501(5) (McKinney Supp. 1977): " 'Radiologist' means a person duly licensed to practice medicine in the state of New York and who is certified by the American Board of Radiology in radiology or by the American Osteopathic Board of Radiology"; id. \$3501(7): " 'Health Physicist' means a person who is certified by the American Board of Health Physics or The American Board of Radiology in physics"; PA. STAT. ANN. tit. 63, § 421.10(b) (Purdon Supp. 1978-79): 
Medicare-Medicaid regulations do not require certification, the federal standards for staff qualification indirectly confirm that it is important. ${ }^{140}$ Specialty certification is a voluntary procedure, and specialty boards play an important role in the initial evaluation of specialists' competence. In effect, the specialty boards, composed exclusively of physician members who are themselves specialists in their respective areas, control access to the field by their specialty certification. This, in turn, has made the specialty boards a prime target for antitrust enforcement.

The standards imposed by specialty boards appear to be substantial and their relevance to general specialty practice and patient protection is usually clear. ${ }^{141}$ However, it is unclear whether the long periods of internship and practice required before a certificate is granted are designed to limit access as well as to provide professional training. That the entire process of specialty certification is closely controlled by the leading professional societies creates a potential for abuse. Yet despite the apparent possibility that the self-certification mechanism may violate the antitrust laws, few reported cases document specific instances of restraints of trade.

The question whether a particular entry barrier in a certification scheme involves a violation of the Sherman Act was presented in Veizaga v. National Board for Respiratory Therapy ${ }^{142}$ where certain test requirements of the National Board for Respiratory Therapy were

\footnotetext{
Physicians who are legally authorized to practice medicine and surgery in other states ... and who apply for training and certification in special departments of medicine and surgery in institutions in this Commonwealth recognized by the board with advice and consultation with the various examining boards in medical specialties approved by the Council on Medical Education of the American Medical Assaciation as proper for such training, shall receive a graduate certificate that is limited to such training. . . Any person who has been certified in a specialty discipline recognized by the board, and who makes an application for licensure to practice medicine and surgery without restriction in the Commonwealth, ... . may be given a qualifying examination.

140. "Under no circumstances is the accordance of staff membership or professional privileges in the hospital dependent solely upon certification, fellowship, or membership in a specialty body or society. All qualified candidates are considered by the credentials committee." 20 C.F.R. $§$ 405.1023(e)(4) (1977) (emphasis added).

141. Courts will not interfere with the determinations of private accrediting agencies or associations, either on due process or antitrust grounds, if the determination is based on substantial evidence and is not arbitrary or unreasonable, and if it is reasonably related to the legitimate professional purposes of the accrediting association. As reflected in the cases, such a legitimate professional purpose must include a measure of public benefit or protection. See, e.g., Marlboro Corp. v. Association of Independent Colleges \& Schools, Inc., 556 F.2d 78 (1st Cir. 1977); Marjorie Webster Junior College, Inc. v. Middle States Ass'n of Colleges \& Secondary Schools, Inc., 432 F.2d 650 (D.C. Cir.), cert. denied, 400 U.S. 965 (1970); Rockland Inst. v. Association of Independent Colleges \& Schools, 412 F. Supp. 1015 (C.D. Cal. 1976); Kronen v. Pacific Coast Soc'y of Orthodontists, 237 Cal. App. 2d 289, 46 Cal. Rptr. 808 (1965); Salter v. New York Psychological Ass'n, Inc., 14 N.Y.2d 100, 248 N.Y.S.2d 867 (1964).
}

142. 1977-1 Trade Cases \ 61,274 (N.D. Ill. 1977). 
challenged under sections 1 and 2 of the Sherman Act. The court reviewed the test practices and remanded for a determination of the nature of the activity regulated. In the court's view, if the activity is commercial, a per se rule of Sherman Act liability should be applied. On the other hand, if the activity is professional or non-commercial, then the rule of reason should be applied to the specific facts of the case. The rule of reason examination is clearly the more appropriate approach to examining the impact of medical specialty certification standards.

The inbreeding encouraged by certification requirements which, in addition to requiring specific training, limit internships to certain approved institutions has also provoked litigation. In United States Dental Institute v. American Association of Orthodontists, ${ }^{143}$ the operators of a private dental school sued the specialty association of orthodontists, the American Dental Association and its officers. The plaintiff school taught orthodonty skills to general practice dentists by giving monthly three-day seminars over a period of five years, thus allowing practicing dentists to acquire specialist skills without dropping out of practice to attend school. It charged that the defendants had conspired to destroy the school in order to restrict the number of practitioners of orthodonty and protect the defendants' monopolistic position. The activities charged included efforts to prevent the State of Illinois from issuing its approval and charter to the school; efforts to have the state approval and charter revoked; issuance of guidelines for continuing dental education which eliminated plaintiff school from the defendants' list of approved educational programs; refusal to publish listings of plaintiff's courses and lists of qualified faculty members in publications controlled by the defendants; and issuance of an advisory opinion that it was unethical for an Association-certified orthodontist to participate as a faculty member in an educational program not approved by the Association. Individual dentists claimed that they had been unable to receive training in orthodonty elsewhere, and that their incomes had thereby been reduced because they had been forced to refer all orthodonty patients. In upholding the cause of action for group boycott against a motion to dismiss, the court noted that the defendants could not assert that they were merely setting and upholding professional standards for public protection when they were adopting restrictive standards to prevent general practice dentists from performing orthodonty and at the same time preventing them from getting training in orthodonty. This holding is clearly applicable to specialty certifica-

143. 396 F. Supp. 565 (N.D. Ill. 1975). 
tion in other professions. If a specialty board insists on certain kinds of training which it controls, it may not then place additional limits on access to such training or boycott analogous training which it does not control. ${ }^{144}$

The specialty boards have become a frequent target of the FTC in recent years, and several actions against specialty organizations and boards have ended in consent decrees. ${ }^{145}$ It is noteworthy that none of these decrees dealt with matters of competency or professional certification. They were limited to clearly economic controls, such as the distribution and compilation of relative value fee scales, price fixing and deprivation of consumer information. In a recent complaint, the American Dental Association also was charged with the latter two economic controls as well as with efforts to retard the development of innovative dental delivery systems. ${ }^{146}$

\section{E. Medical Discipline and Federal Legislation: PSROs.}

Under Medicare and Medicaid, both enacted in $1965,{ }^{147}$ the federal government spends over thirty-one billion dollars annually for medical care. ${ }^{148}$ With government spending very substantial amounts of public funds for health care, its regulatory concerns have, for some time, justifiably addressed matters of cost and quality control, to ensure that government reimburses only for necessary services of good quality actually rendered, in order to reduce costs and conserve scarce resources. ${ }^{149}$

144. In rendering its decision, the court found that it had subject matter jurisdiction under the Sherman Act because the boycott would affect interstate commerce. Id. at 576-77. The court also disposed of the asserted "learned profession exemption", id. at 579-80, and of a motion, based on the Noerr-Pennington doctrine, to strike the part of the complaint that alleged interference with the right to petition public authorities. The court relied on California Motor Transp. v. Trucking Unlimited, 404 U.S. 508 (1972), where the Supreme Court found that the doctrine did not save a defendant where there was an intent to interfere in a business relationship of a competitor, and where the appeal to public authorities was shown to be in bad faith. 396 F. Supp. at 581-83.

145. See, e.g., The American College of Radiology, 3 TRADE REG. REP. (CCH) I 21,236 (Mar. 1, 1977); American College of Obstetrics and Gynecology and American Academy of Orthopedic Surgeons, 3 TRADE REg. ReP. (CCH) If 21,171 (Dec. 14, 1976).

146. American Dental Ass'n, 3 TraDe Reg. ReP. (CCH) ๆ 21,255 (Jan. 4, 1977).

147. 42 U.S.C. $\$ \S 1395-1395 p p, 1396-1396 i$ (1970 \& Supp. V 1975).

148. Current expenditures for health care amount to almost eight percent of the gross national product. For fiscal 1977, total federal expenditures for Medicare were $\$ 21,549,000,000$, BUDGET OF THE UNIted States Government, Fiscal Year 1979, at 181, and federal contributions to Medicaid amounted to $\$ 9,713,287,000$. Id. app. 416 .

149. Since Medicare and Medicaid are systems in which government, as a third-party payer, provides payment for services incurred by patients on a fee-for-service basis, cost and quality controls are of crucial significance, because the patient has little interest in limiting costs and insufficient knowledge to monitor quality. On cost and quality control problems in relation to 
Federal law and regulation have established a number of mechanisms designed to achieve cost and quality control. Unlike other disciplinary mechanisms, these are not intended to secure compliance with the state medical practice acts, except insofar as they require physicians to perform with at least minimal professional competence. However, these federally established mechanisms, currently embodied in the PSROs, will provide data that could be used in, or that could trigger, state disciplinary proceedings. ${ }^{150}$ The PSRO system is an extension of professional peer review ${ }^{151}$ which is intended to replace another scheme of peer review built into Medicare and Medicaid, namely the system of "utilization review."152

PSROs, see Havighurst \& Blumstein, Coping with Quality/Cost Trade-Offs in Medical Care: The Role of PSROs, 70 Nw. U.L. Rev. 6, 9-13 (1975).

150. See text accompanying notes 63-98 supra. Aside from PSROs, federal law relating to third-party payment under Medicare and Medicaid provides remedies for abuses and frauds to deal with such matters as intentional over-billing, billing more than once for a service, billing for services not performed, or billing for services rendered not because they were necessary but for the sake of increasing the bill. Remedies for abuse and fraud include recoupment of excessive payments, 42 U.S.C. $\$ 1395 \mathrm{gg}$ (1970); suspension or termination of physicians from the Medicare and Medicaid programs, 42 U.S.C. $\$ 1395$ (d) (1970); criminal prosecution for fraud, 42 U.S.C. $\$ \S$ 1395nn, 1396h (Supp. V 1975), and, following federal action, information to state disciplinary bodies relating to criminal convictions or other federal action which may then provide the basis for state disciplinary proceedings leading to possible license suspension or revocation, or other state disciplinary sanctions. 42 U.S.C. $\S \S 1395 y(e)(2)(B)(1970)$. While these federal remedies relating to Medicare and Medicaid abuse and fraud raise significant issues relating to professional discipline and to controls of expenditures, they do not appear to raise problems of restraints of trade or of anticompetitive impact in the absence of evidence that they are applied selectively or in some retaliatory manner.

For a discussion of the potential use of PRSO information by state disciplinary bodies, see notes 162 infra and accompanying text.

151. On the constitutionality of the PSRO law, see Lang v. Berger, 427 F. Supp. 204 (S.D.N.Y. 1977). The PSRO system is not a system of control over the practice of medicine which violates \$ 1395, nor does it interfere with a physician's right to practice his profession. American Medical Ass'n v. Mathews, 429 F. Supp. 1179, 1202-03 (N.D. Ill. 1977); Association of Am. Physicians and Surgeons v. Weinberger, 395 F. Supp. 125, 132 (N.D. Ill. 1975).

152. In general terms, utilization review was intended to provide for the examination of the uses of health facilities and institutions to prevent waste and misapplication of scarce resources. In particular, it was intended to ensure that long hospital stays for expensive inpatient treatment occur only when medically necessary. 42 U.S.C. \& 1395x(k) (1970). The PSRO system strongly resembles the earlier scheme of utilization review in relying on professional self-regulation and peer review, with government underwriting the effort and imposing organizational requirements without, however, setting standards or playing a major role in their enforcement. The PSROs scheme was enacted without repeal of the utilization review provisions in part because the establishment of PSROs and their full operational effectiveness were expected to take time. However, when the PSRO is deemed competent as a reviewing body, the earlier statutory utilization review provisions will no longer be applicable. 42 U.S.C. \& 1320c-1(e) (Supp. V 1975), as amended by Pub. L. No. 95-142, § 5(a), 91 Stat. 1183 (1977); 42 U.S.C. § 1320c-4(e)(1) (Supp. V 1975). Utilization review became a requirement for participating hospitals under Medicare in 1966. 42 U.S.C. \& $1395 \mathrm{x}(\mathrm{x})(1970)$. Utilization review requirements had been included in 1965, in the Standards for Accreditation by the Joint Commission on Accreditation of Hospitals composed of representatives 
Although there is evidence that Congress had intended to establish a mechanism designed primarily to achieve cost controls, the initial direction of the legislation was changed during its passage, and was further redirected following its passage when HEW directives relating to PSROs continued to stress quality control and deemphasized matters relating to costs. ${ }^{153}$ In part, this change in emphasis is reflected in the structure of PSROs which emphasizes peer review by local physicians and which provides substantial opportunities for local and state medical society influence. ${ }^{154}$

To be designated a PSRO, a professional organization must have the following characteristics: first, it must be a nonprofit professional organization operating in the area; second, its membership must represent a substantial portion of the physicians in the area; third, membership must be voluntary; fourth, membership must be open to all physicians in the area without regard to membership in, or payment of dues to, any medical society or association; fifth, the organization must be able to make available professionally competent personnel to review the health care services for which PSROs are responsible; and finally, the organization must not restrict member eligibility for service in the PSRO. ${ }^{155}$

It is evident that the federal law does not allow state or local medical societies to function as PSROs because this would condition membership in the PSRO on membership in, or the payment of dues to, a medical society, contrary to the statute. Nonetheless, the requirements for PSROs assure that only an organization acceptable to the local or state medical society will be designated as a PSRO.

of the American Medical Association and the American Hospital Association. See ARTHUR D. Little, InC., AN Evaluation of the EfFectiveness of Utilization Review Activities in Hosprtals 17 (Final Report on Contract HJM 110-71-192, 1972).

153. See generally Havighurst \& Blumstein, supra note 149, at 60-68.

154. The Secretary was to establish PSRO areas in accordance with criteria which emphasize local control. As far as possible, areas are not to exceed a physician population of 2,500. The nation has been divided into 203 PSRO areas, most of them local areas, though twenty-eight states, including the state of Georgia and Washington, each with over 4,000 practicing physicians, were designated as single state PSRO areas. In each of the PSRO areas, the Secretary of HEW designates a qualified professional organization as the PSRO for that area. U.S. DEP'T OF HEW, PSRO PROGRAM MANUAL ch. II § 204.4 (1975).

When the Secretary has determined that an organization is qualified and prepared to serve as a PSRO, he gives notice to the physicians practicing in the PSRO area of his intent to enter into a PSRO agreement with the organization. If more than ten percent of the physicians object, he must conduct a poll to determine that at least 50 percent of the physicians in the area consider the organization to be sufficiently representative of area physicians to serve as a PSRO. 42 U.S.C. $\S$ $1320 c-1(f)(1970)$.

155. 42 U.S.C. § 1320c-1(b)(1)(A) (Supp. V 1975); Association of Am. Physicians and Surgeons v. Weinberger, 395 F. Supp. 125, 140 (N.D. Ill. 1975). 
The local PSRO has primary responsibilty for the setting and review of professional standards. ${ }^{156}$ This is likely to give the local medical society a great deal of power, and although Congress and HEW have created other regulatory bodies, it is unlikely that these will detract significantly from the power wielded by state and local medical societies working with and through PSROs. The review sytem also provides for statewide councils ${ }^{157}$ and a national council to aid in coordinating activities and disseminating information. ${ }^{158}$

The PSRO hospital review system is comprised of three elements: concurrent review of hospital admissions and continued care; medical care evaluation studies (MCE); and analysis of hospital, practitioner and patient profiles. ${ }^{159}$ Congress apparently intended the profile analysis component to be a very important part of the system and one which could have significant implications for physician discipline. ${ }^{160}$

The analysis of physician profiles could be used to enforce the practitioner's statutory obligation to meet professionally recognized standards of health care. Physician profiles would also enable PSROs to determine physician needs for continuing medical education, and would assist state licensing boards in setting their continuing education requirements. Profiles of physicians who create risks to patients that raise a question of their competence to practice medicine could be used

156. 42 U.S.C. § 1320c-4(a)(1) (Supp. V 1975).

157. In any state with two or more PSROs, a Statewide Professional Standard Review Council may be established through a majority vote of the practicing physicians in each PSRO area. 42 U.S.C. \& 1320c-1(g)(1) (Supp. V 1975).

158. 42 U.S.C. $\& 1320 \mathrm{c}-5$ (c) (Supp. V 1975). The hope has been expressed that the National Council will aid in breaking down the dominance of local community standards despite the emphasis of the PSRO statute on local standards. The National Council is to develop data on regional standards of medical quality and communicate such data to local PSROs. It has been suggested that this nationwide comparison of standards will tend to temper the emphasis on local standards when comparison shows the regional standards to be more effective. The suggestion of such a significant role for the National Council is probably overly-optimistic. The emphasis on local, rather than national, standards was a distinct victory for AMA interests, who saw a greater opportunity for influencing the process at the state, rather than the national level, because at the state level the interests of the medical societies and the state regulatory mechanisms overlap most closely. Havighurst \& Blumstein, supra note 149, at $47-48$. Not only was the emphasis on local, rather than national, standards an AMA victory, but it was also a clearly regressive step. For years the emphasis in medical training and in professional standards had been to approach national uniformity of qualification and performance. Indeed, in medical malpractice litigation, the standard of professional competence in recent years has increasingly been the national standard-because the regional or local standard asserted in the defense against malpractice claims has invariably been the lower standard. See Brune v. Belinkof, 354 Mass. 102, 109, 235 N.E.2d 793, 798 (Super. Ct. 1968); Faulkner v. Pezeshki, 44 Ohio App. 2d 186, 192, 337 N.E.2d 158, 163 (Ct. App. 1975).

159. 42 U.S.C. \& 1320c-4(a)(1)-(a)(4) (Supp. V 1975); U.S. DEP'T OF HEW, PSRO PrograM Manual, Ch. II \& 204.4 (1975).

160. S. Rep. No. 1230, 92d Cong., 2d Sess. 261 (1972). 
to trigger disciplinary proceedings if such profiles were made available to appropriate state medical boards. However, it is unlikely that profile analyses will be used for such purposes. A far more limited use is envisaged, with the profiles serving essentially as a check on other review components. Moreover, since PSROs will not for some time address the performance of physicians in their office practices, ${ }^{161}$ the number of individual physician profiles available is likely to be limited. In addition, it is probable that the use of physician profiles for disciplinary purposes will be limited by unclear legal provisions and narrow regulations which will not allow information to be freely provided by PSROs to state disciplinary agencies. ${ }^{162}$

The PSRO system itself provides for a variety of sanctions, apart from any possible uses of PSRO information in state proceedings. If the PSRO determines that the provision of health care services does not meet the requirements of medical necessity, conformity with quality standards, or, in the case of inpatient services, economy, the most direct sanction is the disallowance of Medicare or Medicaid reimbursement; this sanction provides for prior notification of both practitioner and patient when feasible. When there has been either substantial failure to comply with the obligation to provide care which is medically necessary and which meets professionally recognized standards, or gross and flagrant violation of such obligation on one or more occasions, a physician may be excluded from future eligibility for Medicaid or Medicare

161. Under the PSRO statute, review is initially limited to inpatient short-stay general hospitals with review of long-term care facilities to be implemented more slowly.

Ambulatory care provided to Medicare or Medicaid patients was not required to be reviewed under the original PSRO legislation but under the 1977 amendment the Secretary of HEW is required to develop effective methods for the review of ambulatory care by PSROs within two years. Such reviews may be ordered within two years of the time the PSRO has achieved operational status. 42 U.S.C. $\$ 1320 \mathrm{c}-4$ (g) (Supp. V 1975), as amended by Pub. L. No. 95-142, \& c(1)(D), 91 Stat. 1184 (1977).

162. The PSRO statute is not clear on the potential of the use of PSRO information by state disciplinary bodies. On the one hand, the Secretary is to provide by regulation for the "correlation of activities, . . . interchange of data and information, and . . . other cooperation . . . between and among . . . any other public or private agency . . . having review or control functions . . . " 42 U.S.C. \& 1320c-14-14(a)(1) (Supp. V 1975). On the other hand, another section provides that "any data or information acquired by any . . . [PSRO] . . . shall be held in confidence and shall not be disclosed to any person except ... in such cases and under such circumstances as the Secretary shall by regulations provide to assure adequate protection of the rights and interests of patients, health care practitioners, or providers of health care." Id. $\S 1320 \mathrm{c}-15$ (a). Provisions added to the confidentiality section by amendment in October 1977 imply that disclosure is to be limited to evidence of fraud and abuse. Id. $\$ 1320 \mathrm{c}-15(\mathrm{~b})$, as amended by Pub. L. No. 95-142, 91 Stat. 1189 (1977). Thus, it is unlikely that PSRO information on physician competence will become available for state disciplinary proceedings unless fraud and abuse are involved. The 1977 amendment displays a considerable concern, therefore, for the protection of physicians. 
reimbursement. ${ }^{163}$ As a condition of continued eligiblity, he can be required to pay back to the United States the cost of the substandard care up to $\$ 5,000 .^{164}$

The PSRO system raises a number of antitrust issues. It is a system of peer review run entirely by physicians, in particular by a group of local physicians who not only are encouraged, but also are required by federal law to apply local standards. Thus, the nature of the PSROs makes them virtually dependent upon state and local medical societies. Although PSROs are too recent and undeveloped to have given rise to actual complaints of restraints of trade, it requires little ingenuity to project a number of not-so-hypothetical cases.

For example, in setting its local standards, it would not be difficult for the PSRO to impose physician backup and other personnel requirements which would make it impossible for alternative medical facilities to provide low cost abortions. ${ }^{165}$ Moreover, these requirements could be justified on the almost unassailable grounds of patient protection and desirably high standards of medical care.

Similarly, it would not be difficult for a local PSRO, consisting exclusively of local physicians with significant interests in continuing their private practices, to set standards relating to the use of physicians' assistants and other allied health personnel so as to limit their economic use, thereby jeopardizing relatively lower cost prepaid medical plans such as HMOs. The opposition of medical societies to prepaid plans, HMOs and other schemes which do not seek fee-for-service is a matter of history, ${ }^{166}$ and there is little evidence that there has been any major change in attitudes.

The PSRO system also creates a situation where it will not be difficult to "gang up" on physicians who are not in favor with the local society when physician profiles are developed and hospital admissions and other professional matters are reviewed. ${ }^{167} \mathrm{~A}$ few questionable denials of admission, a few refusals to extend hospital stays, and the probability of denials of reimbursement-without any realistic oppor-

163. 42 U.S.C. $\$ 1320 \mathrm{c}-9$ (b)(1) (Supp. V 1975).

164. Id. Such a payback penalty and other sanctions may be imposed only after a rather detailed and full review which includes review by the Statewide Council and a hearing by the Secretary. Judicial review for claims exceeding $\$ 1,000$ is provided. Id. $\$ 405(\mathrm{~b})$, (g) (1970).

165. See discussion of Feminist Women's Health Center v. Mohammad, 415 F. Supp. 1258 (N.D. Fla. 1976), at note 29 supra.

166. See, e.g., AMA v. United States, 317 U.S. 519 (1943).

167. Cf. Falcone v. Middlesex County Medical Soc'y, 34 N.J. 582, 170 A.2d 791 (1961) (unwritten rule of county medical society excluded from membership a duly licensed and registered physician who had not graduated from an AMA-approved medical college). See note 109 supra. 
tunity for timely appeals of such decisions ${ }^{168}$ - and the physician's professional prospects may be substantially diminished.

Federally sponsored peer review organizations engaged in carrying out a significant federal policy should be free from antitrust constraints unless a real case of the kind suggested above can be made against them. However, because a local PSRO, as defined and required by law, is a private organization with a government contract and a set of functions and obligations specified by federal law and regulations, it clearly is not immune from antitrust prosecution. ${ }^{169}$ Indeed, the role of the local PSRO bears some similarity to the role of the stock exchange as described in Silver v. New York Stock Exchange. ${ }^{170}$ Justice Goldberg, speaking for a divided court, outlined the development of the exchange from a private club of dealers in securities to a recognized entity with designated functions under the Securities Exchange Act ${ }^{171}$ and then explained the nature of the problem:

The difficult problem here arises from the need to reconcile pursuit of the antitrust aim of eliminating restraints on competition with the effective operation of a public policy contemplating that securities exchanges will engage in self-regulation which may well have anticompetitive effects in general and in specific applications. ${ }^{172}$

The analogy between the development from private peer review within medical societies to federally sponsored PSROs and the development of the role of the stock exchange is not too remote. Both the stock exchange and PSROs are private organizations that have been given recognition by federal law. In both instances, a private organization has been delegated the public function of self-regulating an occupation or profession, and in both situations self-policing can easily turn into anticompetitive, exclusionary self-protection.

The Silver Court ruled that the "statutory scheme" of the Securities Exchange Act was "not sufficiently pervasive to create a total exemption from the antitrust laws"173 and found a per se violation of the Sherman Act. Abusive exercises of delegated powers of self-regulation by a PSRO may have similar antitrust consequences.

168. See Hultzman v. Weinberger, 495 F.2d 1276 (3d Cir. 1974).

169. The role of the local PSRO may be analogous to that of the integrated bar in Goldfarb. See text accompanying notes 7-8 supra.

170. 373 U.S. $341,349-51$ (1963).

171. Id. at $350-52$.

172. Id. at 349 . Significantly, the Court referred to a "federally mandated duty of self-policing." Id. at 352.

173. Id. at 361 . The case involved the unexplained and procedurally defective denial by the New York Stock Exchange of direct telephone lines and stock ticker connections to non-member securities dealers, who, in consequence of this denial, were effectively disabled from carrying on their business. 
Silver joined a line of cases which have dealt with the problem of harmonizing or reconciling federal antitrust laws not with state, but with federal regulatory statutes. ${ }^{174}$ The common conclusions in these cases have been that a federal regulatory statute does not provide immunity from antitrust enforcement, and that both laws will be given effect to the fullest extent possible. ${ }^{175}$ In the case of PSROs there is no irreconcilable conflict. On the contrary, the constraints of the Sherman Act are more likely to keep PRSOs honest by compelling them to focus on regulations and standards that are protective of patients rather than of local physicians.

The composition of PRSOs makes them particularly subject to antitrust concern. An official regulatory board is not immune from sanctions when it is composed entirely of members of the regulated profession, and when the issue before the board places its members in the adversary position of competitors rather than neutral regulators. PSROs, in their relationship with HMOs or other, less conventional providers of health services, may well find their members in similar competitive positions. ${ }^{176}$

\section{CONCLUSION}

Medical discipline-the regulation of the professional practice of physicians - is not a neatly ordered field. It consists of several regulatory layers and reflects state and federal policies as well as professional self-regulation by private professional organizations, certifying bodies and hospitals. Thus, a physician is licensed by a state regulatory body, but he is certified as a specialist by a private specialty organization. He is subject to the professional discipline of his private local or state medical society, his own state medical board and the peer review group within the hospital where he works. If he has Medicare or Medicaid patients, he is also subject to his local or state PSRO, which is a private organization operating under federal sponsorship with delegated responsibilities of self-regulation. Although he is subject to professional discipline from a variety of agencies or bodies, it is very likely that the actual control of his professional conduct is far more unified than

174. In Silver, the Court, commenting on its own decision, added:

We have today provided not a brake upon the private partner executing the public policy of self-regulation but a balance wheel to insure that it can perform this necessary activity in a setting compatible with the objectives of both the antitrust laws and the Securities Exchange Act.

Id. at 367.

175. Carnation Co. v. Pacific Westbound Conference, 383 U.S. 213, 217-19 (1966); United States v. Philadelphia Nat'l Bank, 374 U.S. 321, 348, 350-51 (1963); California v. FPC, 369 U.S. 482, 485 (1962); United States v. Borden Co., 308 U.S. 188, 198-99 (1939).

176. See note 88 supra and accompanying text. 
would first appear, because all of these agencies and bodies are part of a single network with both formal and informal lines of connection.

To be admitted to practice, the physician must show that he has a medical degree from an accredited medical school. Although the accreditation, in form, is that of the state medical board, it actually is that of an accrediting body of the AMA. He must also pass a qualifying examination. Again in form it is an examination required by the state medical board, while in actual practice it is one of three national examinations prepared by, or with the cooperation of, major national organizations including the AMA. If the physician wishes to become a specialist-as most do-he must meet the requirements of a particular specialty board, which include the completion of an approved residency in an accredited hospital. Such residencies are approved by a committee of national medical and specialty groups including the AMA, and the hospital is accredited by the Joint Committee on the Accreditation of Hospitals, in which the American Hospital Association and the AMA hold membership.

After he has been licensed by the state medical board, the physician is subject to its regulation and continuing discipline. The state medical board is composed of a majority, usually a large majority, of physicians who generally have been named to membership from lists supplied to the governor by state and local medical societies. Indeed, in at least one state, the governing body of the state medical society is the state medical board. In any event, the state medical societies, which generally are subsidiaries of the AMA, provide a number of services to the state board. They may assist the state board in developing the required continuing medical education, in supervising disabled physicians who are on probation or in limited practice and in supplying information to the medical board regarding instances in which a physician has been disciplined by the state or local medical society. In a small number of states, the medical society is charged with investigating violations of the medical practice act for the state medical board.

The physician's hospital practice is subject to internal peer review procedures, generally in accordance with recommendations of the Joint Committee on the Accreditation of Hospitals. His grant of privileges to treat his patients at the hospital is likely to be facilitated by his membership in the local or state medical society. It will also be eased by his status as a board-certified specialist.

The physician's professional performance in the hospital is subject not only to review by hospital peer review committees, but also, if he treats Medicare and Medicaid patients, it is, or shortly will be, subject to review by the local PSRO. This organization of his peers, while hav- 
ing no formal connection with the local or state medical society, is probably closely connected with it because of the manner in which PSROs are established.

In spite of this substantial peer review apparatus, the outcome of professional discipline, whether administered by the state or a medical society, has been minimal. The lack of statistics on the subject is itself a matter that engenders skepticism. The minimal figures that are available show that of some 325,000 physicians in the United States, fewer than one hundred have their licenses revoked each year, and only a very few are disciplined by their own medical societies.

Does any of this point to sinister, wholesale conspiracies in restraint of trade by the medical profession? Probably not. But it does point to a cozy, close relationship of the regulators and the professionals they are regulating, relationships which provide ample opportunities for abuse and for practices that may have an anticompetitive impact. Thus, antitrust enforcement, or the threat of such enforcement, against the would-be regulators and self-regulators may enhance the effectiveness of the regulatory process. Antitrust enforcement does not conflict with sound professional regulation, and nothing in the Goldfarb case would produce such a conflict. There is a need for sound regulation of the quality of medical care, and for the policing of incompetence in professional practice. Federal antitrust laws do not interfere with the enforcement of sound professional standards promulgated in the exercise of the states' police power, nor do they interfere with professional self-regulation that is designed to protect the public and uphold professional standards, even when such state regulation or selfregulation has incidental anticompetitive effects. On the contrary, antitrust enforcement is far more likely to promote sound professional influence on the disciplinary scheme by eliminating improper selfprotective and economic restraints that encumber the system. 